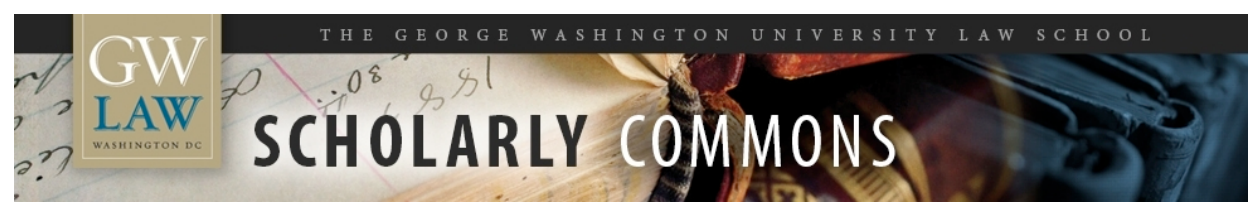

\title{
Sites of Redemption: A Wide-Angle Look at Government Vouchers and Sectarian Service Providers
}

Ira C. Lupu

George Washington University Law School

Robert W. Tuttle

George Washington University Law School

Follow this and additional works at: https://scholarship.law.gwu.edu/faculty_publications

Part of the Law Commons

\section{Recommended Citation}

Robert W. Tuttle \& Ira C. Lupu, Sites of Redemption: A Wide-Angle Look at Government Vouchers and Sectarian Service Providers, 18 J.L. \& Pol. 539 (2002).

This Article is brought to you for free and open access by the Faculty Scholarship at Scholarly Commons. It has been accepted for inclusion in GW Law Faculty Publications \& Other Works by an authorized administrator of Scholarly Commons. For more information, please contact spagel@law.gwu.edu. 


\title{
Sites of Redemption: A Wide-Angle Look at Government Vouchers and Sectarian Service Providers
}

\author{
Ira C. Lupu and Robert Tuttle* \\ Post-Script: Zelman v. Simmons-Harris, 70 U.S.L.W. 4683 (No.00- \\ 1751, June 27, 2002) \\ On the final day of the 2001-02 Term, the U.S. Supreme \\ Court handed down its decision in Zelman $v$. Simmons-Harris, the \\ case involving the constitutionality of the Cleveland voucher \\ program. In a 5-4 decision, the Court (per Rehnquist, CJ) held that \\ programs that give parents a "true," "genuine" and "independent" \\ choice among various educational options may include scholarships \\ for use at sectarian schools among those options. The Court \\ concluded that the Cleveland program met the constitutional \\ requirement of "true private choice." The dissenting Justices \\ rejected the majority's emphasis on intervening private choice, and \\ would have held the Cleveland program to be a violation of the \\ Establishment Clause because the program resulted in a transfer of \\ money, unrestricted as to use, from the state to sectarian schools.
}

We presented this piece several days prior to the oral argument in Zelman, and we completed our substantive work on the article prior to the decision in Zelman. The Zelman opinion relies almost exclusively on a norm of intervening private choice as insulation between the state and religious institutions, but the opinion is radically untheorized - it relies almost exclusively on precedent and fails to explain the constitutional significance of

\footnotetext{
* Ira C. Lupu is the Louis Harkey Mayo Research Professor of Law at George Washington University Law School; Robert Tuttle is a Professor of Law at George Washington University Law School. The authors are the co-directors of the Legal Tracking Project of the Roundtable on Religion and Social Welfare, sponsored by the Pew Charitable Trusts. The opinions in the article are those of the authors, and do not necessarily reflect the views of the Pew Charitable Trusts. Our thanks to Dean Michael Young of the George Washington University Law School for financial support for this project; to Vince Blasi, Marty Lederman, Jim Ryan, and our colleagues at George Washington for helpful comments on an earlier version of this paper; and to Michael Patrick for invaluable research assistance.
} 
The Journal of Law and Politics

private choice. Moreover, it does not grapple with how to measure the validity of that choice in constitutional terms.

This paper, though antecedent in time to Zelman, may help fill some of the jurisprudential gaps left by the opinion. We too rely on a theory of "genuine and independent" private choice as a metric of permissible voucher programs that include sectarian providers, but we do our best to explain that theory in detail, and to analyze the ways in which application of that theory may vary from context to context. The Court did not pursue our suggested lines of inquiry into the extent to which voucher programs steer beneficiaries into religious experience. Nor did it ask, as we do in this piece, what steps the state should take to absolve itself of responsibility for any religious experience undergone by voucher recipients. Nevertheless, we think the article has much to offer a reader in search of a theoretical grounding for the approach in Zelman. We hope that our emphasis on service contexts other than education will be particularly illuminating.

We have many specific observations about the Zelman opinions, and we expect to offer that commentary in forthcoming work. Here, we limit ourselves to the view of vouchers, sectarian providers, and the state that occupied our minds in the winter and spring of 2002.

Those who design government services select from a thick catalogue of options. The first and most basic choice designers face is whether government agents should deliver the service directly to recipients, as in the case of public schools, or whether government instead should finance private providers of such services. If government prefers to operate through private entities, it then can choose between two general approaches to financing the services. In the first approach, the financing scheme depends on decisions made by the service recipients. Programs involving recipient choice include child care, ${ }^{1}$ schemes of public support for private education, ${ }^{2}$ and substance

\footnotetext{
${ }^{1}$ Child Care and Development Block Grant Act of 1990, 42 U.S.C. § 9858n(2) (1994 \& Supp. V, 1999).

${ }^{2}$ These include programs in support of higher education. See, e.g., Witters v. Wash. Dep't. of Servs. for the Blind, 474 U.S. 481 (1986). Most of the controversy about voucher programs, however, has
} 


\section{Vouchers and Religious Service Providers}

abuse treatment. In these and similar programs, which we will refer to hereafter as voucher programs, eligible recipients are authorized to select among providers, which then may collect payment from the government for services rendered. ${ }^{3}$ Alternatively, in arrangements which we hereafter will call non-voucher programs, government finances the work of private social service providers in ways that are not directly tied to the number of recipients served. ${ }^{4}$

At the level of policy, as well as that of constitutionality, significant controversy has arisen over the use of private entities to perform governmental functions. Critics worry, for example, about the loss of accountability, constitutional and otherwise, that typically comes with privatization. ${ }^{5}$ Even in cases in which privatization is uncontroversial, however, there may be serious debate over the appropriate means of financing such service providers. Because non-voucher programs typically produce a flow of cash, not dependent on units of service delivered by the provider, such programs may facilitate budgetary planning, boost fledgling providers, and sustain providers that lack significant financial reserves. In contrast, vouchers may maximize the choices available to recipients and better tailor government expenditures to the services actually provided. ${ }^{6}$

involved elementary and secondary education. The most recent programs of this sort include one in Milwaukee, Jackson v. Benson, 578 N.W.2d 602 (Wis. 1998), cert. denied, 525 U.S. 997 (1998), another in the State of Florida, see http://www.schoolchoiceinfo.org, and a third in Cleveland, Ohio. Id. The constitutionality of the Cleveland program, which we analyze later in this paper, is at issue in the U.S. Supreme Court this Term. Simmons-Harris v. Zelman, 234 F.3d 945 (6th Cir. 2000), cert. granted, 533 U.S. 976 (2001) (No. 00-1751).

${ }^{3}$ Voucher programs may include goods, such as food or shelter, rather than or in addition to, services such as counseling or training. As we define the term, voucher programs do not depend upon the issuance of any certificate or other physical manifestation of the financing scheme; rather, voucher programs earn that characterization by the elements of beneficiary designation of the provider coupled with government payment based on individualized services or goods provided to the beneficiary.

4 These direct arrangements may include grants from the government, or contracts with it. This distinction typically reflects different regimes for making awards and/or monitoring performance. For our purposes in this paper, however, grants and contracts are considered non-voucher programs and are constitutionally indistinguishable.

${ }^{5}$ See, e.g., Jack M. Beermann, Privatization and Political Accountability, 28 FORDHAM. URB. L.J. 1507, 1537-41 (2001); Matthew Diller, Accountability and Democracy in the Era of Privatization, 28 Fordham URB. L.J. 1307 (2001); Martha Minow, Partners, Not Rivals?: Redrawing the Lines Between Public and Private, Non-Profit and Profit, and Secular and Religious, 80 B.U. L. REV. 1061 (2000). For a view that de-emphasizes the accountability worries and emphasizes the benefits of privatization, see Ronald A. Cass, Privatization: Politics, Law and Theory, 71 MARQ. L. ReV. 449 (1988); Clayton P. Gillette \& Paul B. Stephan III, Constitutional Limitations on Privatization, 46 AM. J. CoMP. L. 481 (1998).

${ }^{6}$ Defenders of vouchers frequently assert that programs dependent on recipient choice will be more efficient because, with proper program design, they approximate the conditions of a competitive market, including consumer sovereignty, the entry of new firms, and the demise of failing ones. See MiLton FRIEDMAN, CAPITALISM AND FREEDOM (2nd ed. 1963). For other economic perspectives on vouchers, see David Bradford \& Daniel N. Shaviro, The Economics of Vouchers, in VOUCHERS AND THE PROVISION OF 


\section{The Journal of Law and Politics}

Although that policy debate is important, this paper focuses on the questions of religious exercise and establishment raised by the inclusion of faith-based organizations in voucher programs. The conventional constitutional wisdom, borne out by decisions of the last thirty years, is that non-voucher programs that transfer unrestricted funds to faith-soaked service providers face insuperable constitutional obstacles, ${ }^{7}$ while voucher programs that include such institutions stand a fighting chance to survive. ${ }^{8}$ Indeed, the staunchest defenders of vouchers typically contend that voucher programs solve most, if not all, problems of religious establishment associated with aid to faith-based organizations. ${ }^{9}$ Voucher proponents argue that the choice exercised by service recipients disconnects the government from the religious character of the service provider, thus avoiding Establishment Clause

PuBliC SERVicES (C. Eugene Steurle, et al. eds., 2000). The germinal work on school vouchers from an economic perspective appears in Milton Friedman, The Role of Government in Education, in ECONOMICS AND THE PUBLIC INTEREST (Robert A. Solo ed. 1955). Other commentators focus on vouchers as a way of combating the tendencies of entrenched government bureaucracies in the provision of service, see, e.g., John E. Chubb \& Terry M. Moe, Politics, Markets, and AmericA's Schools (1990), or as an instrument for lifting the poorest children out of failing public schools, see SCHOOL CHOICE AND SOCIAL Controversy: Politics, Policy, AND LAW (Stephen D. Sugarman \& Frank R. Kemerer eds.) (1999).

${ }^{7}$ See, e.g., Lemon v. Kurtzman, 403 U.S. 602 (1971) (holding that state grants of salary supplements to teachers of specified secular subjects in private, sectarian schools violate the Establishment Clause). The Supreme Court's past two encounters with aid to sectarian schools have approved such aid, but neither involved the transfer of unrestricted funds, and both involved programs which limited the aid to secular uses. See Mitchell v. Helms, 530 U.S. 793 (2000) (holding that states and localities may lend educational materials, restricted to secular use, to sectarian schools); Agostini v. Felton, 521 U.S. 203 (1997) (holding that the federal government may pay public employees to teach remedial, secular subjects in private sectarian schools).

${ }^{8}$ See Jackson v. Benson, 578 N.W.2d 602 (Wisc. 1998) (upholding Milwaukee's school voucher program, which includes deeply sectarian schools), cert. denied, 525 U.S. 997 (1998). One of the authors of this piece has expressed the view that a well-designed program of vouchers for use in elementary or secondary schools may well survive Establishment Clause attack. Ira C. Lupu, The Increasingly Anachronistic Case Against School Vouchers, 13 Notre Dame J.L. Ethics, \& PUB. POL'y 375 (1999). The distinction between voucher and non-voucher programs was dramatically illustrated in the recent decision in Freedom from Religion Foundation, Inc. v. McCallum, 179 F. Supp. 2d 950 (W.D. Wis. 2002), in which the Court invalidated, as a violation of the Establishment Clause, a non-voucher arrangement between the state welfare department and Faith Works, a religion-intensive program for substance abusers, but held for trial the question of whether a voucher-type arrangement between the Department of Corrections and Faith Works was constitutional. The crucial question reserved for trial was whether the state could prove that recipients had accepted the services "of their own free choice." Id. at 978.

The Supreme Court decisions that seem best to support the constitutional distinction between voucher and non-voucher programs include Zobrest v. Catalina Foothills School District, 509 U.S. 1 (1993); Witters v. Washington Department of Services for the Blind, 474 U.S. 481 (1986); and Mueller v. Allen, 463 U.S. 388 (1983). But see Comm. for Pub. Educ. v. Nyquist, 413 U.S. 756 (1973). We will discuss these decisions in connection with the Cleveland school voucher case in Part III, infra.

${ }^{9}$ See, e.g., Michael McConnell, Legal and Constitutional Issues of Vouchers, in VOUCHERS AND THE Provision of Public Services, supra note 6, at 368, 385; Eugene Volokh, Equal Treatment is Not Establishment, 13 Notre DAME J.L. ETHICS \& PUB. POL’y 341 (1999). 


\section{Vouchers and Religious Service Providers}

concerns. ${ }^{10}$ Voucher opponents disagree, however, and assert that the financing mechanism is irrelevant. In their view, as long as taxpayer dollars end up in the coffers of religious organizations, the Establishment Clause is offended. ${ }^{11}$

In what follows, we challenge these conventional approaches to the constitutionality of voucher programs. We argue that the presence of vouchers as a financing mechanism is neither dispositive nor irrelevant. In Part I, we briefly describe the theories-Religionism, Secularism, Separationism, and Neutralism - that have tended to dominate discussion of the Constitution's Religion Clauses. We then explain how proponents of these theories might analyze the constitutionality of voucher programs, and we identify theoretical and practical weaknesses with each of these approaches. In Part II.A, we suggest an alternative reading of the Religion Clauses. We believe that the purpose of the Clauses is to exclude the state from the enterprise of religious worship and devotion. Government may not participate in, forbid, require, sponsor, or promote that enterprise.

In line with that central purpose, and consistent with the current law, the core question for any voucher program is the extent to which it is reasonable to impute to the government the recipient's religious experience, if any, arising out of that program. ${ }^{12}$ In Part II.B., we demonstrate that a thorough answer to this question depends on a highly contextualized assessment of each of the three relationships formed by the triangle of government, recipient, and provider. Analysis of the triangulated relationship in turn leads us to a typology of voucher programs, in which the state's responsibilities vary with type. In Part III, we apply the methodology developed in Part II to Cleveland's school voucher program, now before the Supreme Court.

\footnotetext{
${ }^{10}$ Id. at 341-45.

${ }^{11}$ Elliot N. Mincberg \& Judith E. Schaeffer, Grades K-12: The Legal Problems with Public Funding of Religious Schools, in Vouchers AND tHe PROVISION OF PUBlic SERVICES, supra note 6, at 394; see also Marci A. Hamilton, Power, The Establishment Clause, and Vouchers, 31 CONN. L. REV. 807 (1999); Laura S. Underkuffler, Vouchers and Beyond: The Individual as Causative Agent in Establishment Clause Jurisprudence, 75 IND. L.J. 167, 187-90 (2000).

12 See Mitchell v. Helms, 530 U.S. 793, 809 (2000) (plurality opinion); id. at 842 (O'Connor, J., concurring); see also Agostini, 521 U.S. at 226 (1997); Witters, 474 U.S. at 488-89 (1986).
} 


\section{The Journal of Law and Politics}

\section{STANDARD ACCOUNTS OF THE RELIGION ClAUSES, AND THEIR PERSPECTIVES ON VOUCHERS}

In an earlier article, we identified four standard theories of the Constitution's Religion Clauses. ${ }^{13}$ These theories are best understood as two sets of opposing pairs. The first set, reflected across debates in the so-called culture wars, is organized around contradictory answers to the question of whether religion is a social good. The second set, ordinarily framed in the language of law rather than culture, divides over the question of the distinctiveness of religious institutions as compared to nonreligious associations. Mirroring the division in the general culture, on the bench, and within the academy, each set contains one theory constitutionally supportive of vouchers and another, opposing theory hostile to them.

\section{A. Religionists vs. Secularists}

The first set is composed of groups we call Religionists and Secularists. Religionists see religion as an irreplaceable moral resource for society. ${ }^{14}$ They contend that religious piety is crucial to personal ethical development and civic responsibility. Religious institutions and commitments, in this view, constitute a necessary bulwark against the social and moral decline that accompanies secular individualism. Accordingly, Religionists believe that communities of faith should be allowed, on a basis at least equal to that of other groups, to participate in government programs designed to promote the common good. ${ }^{15}$ Many Religionists also believe that government should have broad authority to acknowledge religious themes, traditions, and celebrations. Moreover, Religionists advocate special exemptions from regulatory burdens faced by religious institutions. Religionists thus favor legal outcomes that maximize the benefits to, and minimize the burdens on, religion. In

\footnotetext{
${ }^{13}$ Ira C. Lupu \& Robert Tuttle, The Distinctive Place of Religious Institutions in Our Constitutional Order, 47 VILL. L. REV. 37 (2002).

${ }^{14}$ See, e.g., Carl H. Esbeck, A Constitutional Case for Governmental Cooperation with Faith-Based Social Service Providers, 46 EMORY L.J. 1 (1997); John Garvey, Free Exercise and the Values of Religious Liberty, 18 ConN. L. REv. 779 (1986); Douglas Laycock, The Underlying Unity of Separation and Neutrality, 46 EMORY L.J. 43 (1997); Michael W. McConnell, The Problem of Singling Out Religion, 50 DEPAUL L. REV. 1 (2000). Religionism sometimes goes by the name of "accommodationism." See, e.g., Stephen Carter, The Resurrection of Religious Freedom, 107 HARV. L. REV. 118 (1993); Michael McConnell, Accommodation of Religion, 1985 SUP. CT. REV. 1.

15 See, e.g., Carl H. Esbeck, Myths, Miscues, and Misconceptions: No-Aid Separationism and the Establishment Clause, 13 Notre DAME J.L. ETHICS \& PUB. POL'Y 285 (1999).
} 


\section{Vouchers and Religious Service Providers}

constitutional terms, Religionists argue for a weak Establishment Clause and a strong Free Exercise Clause.

With respect to financing the participation of private institutions in government programs, a consistent Religionist would be indifferent to the choice between voucher and non-voucher forms. So long as religious institutions are included in the mix of service providers, the Religionists' goal of promoting social welfare through faith groups is advanced. Nevertheless, Religionists may find vouchers attractive for several reasons. First, voucher programs seem far more likely to survive constitutional attack than nonvoucher programs. Second, Religionists may believe that voucher programs involve less governmental regulation - with respect to religious content and otherwise - than non-voucher programs. Third, Religionists may think that voucher programs will generate wider involvement of small congregations and community groups than non-voucher programs, which tend to favor larger, bureaucratic, and largely secularized social service providers. ${ }^{16}$

The opposing group, which we call the Secularists, contends that deeply held religious beliefs often pose a threat to social cohesion, inclusiveness, tolerance, and other liberal values. ${ }^{17}$ In contrast to the Religionists' view of faith's constructive power, Secularists tend to see religious institutions as authoritarian and intolerant. Secularists fear that religious forces will use government power to impose a generic - or worse, a sectarian - religiosity on the society. Because religious institutions are perceived as threats to the social fabric, Secularists object to any government program that provides material aid to religious institutions, whether or not such programs encompass a broad mix of the religious and nonreligious. Secularists are not relentlessly hostile to religious institutions; in the Secularist view, government should safeguard the freedoms of private religious expression and association on terms equal to those afforded the nonreligious. Government should not offer, however, any special protections or exemptions to religious individuals or

\footnotetext{
16 Because non-voucher programs must steer clearer of religious content than voucher programs, providers operating under non-voucher arrangements are frequently, though by no means always, professionalized and secularized arms of religious groups. Lutheran Social Ministries, Catholic Charities, and the Jewish Board of Family and Childrens' Services are typical examples of the sort of professional organizations that receive such non-voucher aid. Stephen V. Monsma, The "Pervasively Sectarian" Standard in Theory and Practice, 13 Notre Dame J.L. EThics \& Pub. PoL'Y 321, 322 (1999).

17 See, e.g., JAMES DWYeR, VOUCHERS WITHIN REASON 171-175 (2002); Steven G. Gey, Why Is Religion Special?: Reconsidering the Accommodation of Religion Under the Religion Clauses of the First Amendment, 52 U. PitT. L. Rev. 75 (1990); Marci A. Hamilton, The Constitutional Rhetoric of Religion, 20 U. ARK. LitTLE Rock L.J. 619 (1998); William P. Marshall, The Other Side of Religion, 44 HASTINGS L.J. 843 (1993); Susanna Sherry, Enlightening the Religion Clauses, 7 J. CONTEMP. LEGAL IsSuES 473 (1996); Kathleen Sullivan, Religion and Liberal Democracy, 59 U. CHI. L. REv. 195 (1992); Underkuffler, supra note 11 .
} 


\section{The Journal of Law and Politics}

associations; nor should government be able to engage in religious expression of its own. The Secularist program is therefore associated with a strong Establishment Clause and a weak Free Exercise Clause.

Like Religionists, consistent Secularists should be indifferent to the financing mechanism employed by any government program of material aid to faith-based organizations. Secularists, convinced of the unconstitutionality and undesirability of non-voucher programs, see vouchers as nothing more than a type of money-laundering, ${ }^{18}$ a change only in form of a substantively impermissible practice. That said, Secularists may think vouchers are marginally worse than non-voucher programs because voucher programs tend to minimize the significance of government regulation of service providers. For example, Secularists fear that providers in voucher arrangements may be more free to discriminate on religious grounds in employment, ${ }^{19}$ or to use methods that are more faith-soaked than would be permissible in non-voucher programs. Moreover, Secularists might prefer the professionalized, bureaucratic service agencies typically supported by non-voucher programs, and suspect that vouchers are likely to further the religious missions of small, congregation-based providers rather than meet the secular needs of service recipients.

The Religionist and Secularist positions each capture small and opposing elements of constitutional truth. Religious institutions may indeed advance the common good, and they may act in destructively factional or intolerant ways. The obvious incompleteness and partiality of their respective accounts, however, reveal the common flaws of both Religionism and Secularism. Neither view adequately explains why religious communities and commitments are categorically more dangerous or beneficial than their nonreligious counterparts, so both views seem to be no more than special constitutional pleading on behalf of or against religious entities. Moreover, their obvious partiality makes them relatively poor sources of constitutional insight into the problem presented by vouchers.

\footnotetext{
${ }^{18}$ Underkuffler, supra note 11, at 191 ("we must ... reject the notion that public money can simply be laundered through 'private choice' as a way to avoid Establishment Clause guarantees."); see also Laura S. Underkuffler, The Price of Vouchers for Religious Freedom, 78 U. DET. MERCY L. REV. 463, 473 (2001).

${ }^{19}$ The Salvation Army has been lobbying for a focus on vouchers rather than non-voucher financing in the Bush Administration's charitable choice policy, because Army officials believe that the voucher mechanism will permit escape from the requirements of some cities that all firms with city contracts must provide benefits for domestic partners of employees equal to the benefits provided to spouses of employees. See Dana Milbank, Story of Charity Plea Changes Again: In Latest White House Account, OMB, Not Rove, Takes Lead Role, WASH. POST, July 13, 2001, at A2 (describing attempts by Salvation Army to get the White House to make efforts to alter a proposed charitable choice bill in ways that would permit vouchers to be used instead of grants to finance services by religious entities)
} 


\section{Vouchers and Religious Service Providers}

\section{B. Separationists and Neutralists}

The second set of theorists is made up of groups we call Separationists and Neutralists. Compared to the first set, which tends to dominate in culture and politics, this second set tends to be well-represented on the bench. ${ }^{20}$ Separationists and Neutralists are not defined by their degree of friendliness or hostility to institutions of faith; instead, they are defined by their efforts to provide internally consistent answers to questions concerning the legal distinctiveness of religious organizations.

Separationists hold that religious institutions are constitutionally distinctive for purposes of both benefits and burdens. Separationists believe that firm and clearly defined barriers between government and religious entities are essential to preserve religious purity, civil peace, or both. ${ }^{21}$ Thus, whether the legal context be government-sponsored worship, material aid to religious entities, regulation of employment relations within such entities, or the myriad other ways in which government and religion interact, Separationists consistently aspire to disentangle government from religious practices and communities. In the terms we have used above, the Separationists assert strong versions of both the Establishment Clause and the Free Exercise Clause. ${ }^{22}$

Like Secularists, Separationists tend to regard the distinction between voucher and non-voucher programs as one of form rather than substance. Any program that delivers government funds into the hands of religious entities, by whatever route, is inherently suspect. Unlike Secularists,

\footnotetext{
${ }^{20}$ We analyze the voting patterns of the Justices in terms of Secularism (Stevens, J.), Separationism (Brennan, Blackmun, Marshall, \& Souter, JJ.), and Neutralism (Rehnquist, C.J., Scalia, \& Thomas, JJ) in Lupu \& Tuttle, supra note 14, at nn.48, 50, \& 116. The Court currently includes no Religionist (nor can we think of any Justice in our history who has been a consistent and overt Religionist), although Justice Scalia gets as close as he can to the Religionist view without abandoning various doctrines associated with Neutrality, discussed below. See, e.g., Lee v. Weisman, 505 U.S. 577, 638 (1992) (Scalia, J., dissenting) (arguing that the state's purposes in having prayer at graduation from public schools include "fostering respect for religion.").

${ }^{21}$ Melissa Rogers's paper for this Symposium is a classic illustration of the Separationist account, rooted in the need to protect religious communities against the body politic, and vice versa. Melissa Rogers, Forgotten but Not Gone: Some Ways in which the Separation Tradition Protects Religion and Fosters Religious Liberty, 18 J.L. \& POL. xx (2002). Separationists and Secularists consistently fall back on a theory, originally associated with James Madison, of the coercion of taxpayers as the underlying justification for their views, but they never explain why it is that religious conscience is the only kind that is constitutionally protected in this way, nor do they explain why secular expenditures which violate religious conscience - for abortion, for example - do not fall under a similar ban. For development of these points, see Esbeck, supra note 16, at 311-13; Michael W. McConnell, The Selective Funding Problem: Abortions and Religious Schools, 104 HARV. L. REV. 989 (1991).

${ }^{22}$ The Separationist view is thus, of the four, the one most commonly associated with tension between the Religion Clauses.
} 


\section{The Journal of Law and Politics}

however, who may find voucher programs marginally worse, Separationistsif forced to choose between vouchers and non-voucher programs - might have ambivalent reactions. On the one hand, voucher programs raise the specter of government funds and accompanying regulation reaching a wider range of religious institutions and their programs than prior policies have reached. Thus, vouchers might foster more extensive interaction between government and religious entities. On the other hand, the regulatory control of providers which ordinarily accompanies voucher programs might be considerably less intrusive than the auditing and contractual controls that characterize most non-voucher programs. Despite these often subtle, empirical differences between vouchers and non-vouchers, however, Separationists routinely oppose vouchers on the ground that the distinction between voucher and nonvoucher programs is constitutionally irrelevant. ${ }^{23}$

Neutralists, the fourth camp, deny the Separationist claim that religion is a distinct constitutional category. To Neutralists, religion is but one among many of the human commitments that may either enhance social welfare or threaten social harm. Accordingly, Neutralists believe that government should treat religious and secular commitments identically with respect to the conferral of benefits and the imposition of burdens. Because, in their view, religion is not constitutionally distinctive, Neutralists adhere to a weak view of both the Establishment Clause and the Free Exercise Clause. ${ }^{24}$

Neutralists should be indifferent to the choice between voucher and nonvoucher programs, because their theory focuses solely on the equal distribution of burdens and benefits between religious and nonreligious institutions. Like Religionists, however, Neutralists may be attracted to voucher programs for a pragmatic reason; if well structured, such programs are far more likely to survive constitutional attack than their non-voucher counterparts.

From a constitutional perspective, the second set of theories offers a more principled approach to the relationship between government and religious institutions than does the first set. Both Separationists and Neutralists take internally consistent views of the Constitution's Religion Clauses. Separationists believe that religious institutions are distinctive with respect to

\footnotetext{
23 See, e.g., EdD Doerr ET AL., The CASE Against School Vouchers (1996); Steven K. Green, The Legal Argument against Private School Choice, 62 U. CIN. L. REV. 37 (1993).

${ }^{24}$ Leading Neutralist writing includes Philip Kurland, Of Church and State and the Supreme Court, 29 U. CHI. L. REV. 1 (1961); Mark Tushnet, "Of Church and State and the Supreme Court”: Kurland Revisited, 1989 SuP. CT. REV. 373; Volokh, supra note 9. Neutralists tend to make the Religion Clauses disappear, and therefore face the least inter-clause tension, but Neutralists have trouble explaining why they have effectively made the Religion Clauses superfluous.
} 


\section{Vouchers and Religious Service Providers}

both benefits and burdens; Neutralists believe that they are distinctive with respect to neither benefits nor burdens. Despite this theoretical advantage, this second set shares with the first set an identical flaw. None of these four approaches provides a sufficiently nuanced account of the interactions between government and religion. Like Religionists, Separationists fail to explain why religious institutions deserve insulation from government regulation across the full range of activities, no matter how mundane. Like Secularists, Separationists fail to justify the total exclusion of religious institutions from programs of government aid. Neutralists are equally sweeping in their denial that religion is constitutionally unique in any respect. In the Neutralist view, for example, religious worship - by individuals or government-is completely indistinguishable from other forms of expression or association. All four positions treat religion categorically, and thereby fail to attend to the specific contours of interactions between government and religion. Our theory, developed in the next section, addresses this failure.

\section{OUR ACCOUNT OF THE RELIGION ClAuseS, AND WHAT IT ENTAILS FOR VOUCHERS}

Thus far, we have categorized the dominant strains of Religion Clause theory and have suggested how each addresses the issue of vouchers. ${ }^{25} \mathrm{We}$ have also identified weaknesses in each of the four strains. Each has some element of constitutional wisdom, but all seem to ignore or repress important aspects of the evolving story of the relationship between religion and government. In what follows, we trace the outlines of an alternative theory of the Religion Clauses. With this theory in hand, we then turn to issues raised across a wide range of government voucher programs that involve religion and religious institutions.

\section{A. The Religion Clauses Reconsidered}

First, as between the two sets of views identified in Part I, we believe that the shared perspective of the Separationist-Neutralist pair-that the distinctiveness of religious institutions attaches either to the Establishment Clause and the Free Exercise Clause, or to neither one-is a necessary feature of any constitutionally plausible account of the Clauses. Those who reject this symmetry and contend that government should systematically either favor

\footnotetext{
${ }^{25}$ The four groups, it might be noted, are divided 2-2 on the constitutionality of vouchers redeemable at sectarian organizations, although there appears among them a slight preference for the use of vouchers over non-vouchers on a mixture of empirical or pragmatic grounds.
} 


\section{The Journal of Law and Politics}

or repress religious institutions bear a heavy burden of persuasion, one that neither Religionists nor Secularists have thus far carried.

Second, as between the Neutralists and the Separationists, we believe that the former offer a more constructive starting point. Neutralism captures the arc of recent jurisprudence of the Religion Clauses, ${ }^{26}$ as well as deeper constitutional logic. In an era in which equality norms dominate constitutional understandings, claims of disparate treatment-whether the exclusion of religious entities from government-controlled benefits, or the exemption of such entities from government regulation-demand justification. With respect to most activities engaged in by religious institutions and their agents, such as purchasing property, adhering to norms of building safety, or operating motor vehicles, the state ordinarily has little or no reason to treat such institutions differently from their secular counterparts.

Nevertheless, decisions interpreting the Religion Clauses have retained three core Separationist principles, none of which can be redescribed in Neutralist terms. First, as reinforced in the Supreme Court's decision in Santa Fe Independent School District v. Doe, ${ }^{27}$ government may not engage in or promote religious worship, though it remains free to engage in or promote any other type of speech. ${ }^{28}$ Second, although government may provide aid for secular purposes to religious institutions, a majority of the Supreme Court in Mitchell v. Helms ${ }^{29}$ held fast to the principle that the government must prohibit the diversion of such aid to religious purposes. ${ }^{30}$ Third, the Supreme Court's most robust embrace of Neutralism, Employment Division v. Smith, ${ }^{31}$ highlights the continuing significance of Separationism by reminding us that courts may not "lend . . . power to one or the other side in controversies over

\footnotetext{
${ }^{26}$ In Mitchell v. Helms, 530 U.S. 793 (2000), a four-Justice plurality adopted the view that the Establishment Clause requires no more from aid programs than a religion-neutral class of beneficiaries and a religion-neutral content to the aid itself. See also Mueller v. Allen, 463 U.S. 388 (1983). On the Free Exercise side, Employment Division v. Smith, 494 U.S. 872 (1990), which strenuously rejected a doctrine of free exercise exemptions from laws of general applicability, is a powerful statement in the direction of Religion Clause neutrality. The line of decisions protecting the claims of religious speakers to equal access to public fora are consistent with this trend. See, e.g., Good News Club v. Milford Central Sch., 533 U.S. 98 (2001); Rosenberger v. Rector of the Univ. of Virginia, 515 U.S. 819 (1995); Lamb's Chapel v. Center Moriches Union Free Sch. Dist., 508 U.S. 384 (1993).

27530 U.S. 290 (2000).

28 See id.

29530 U.S. 793 (2000).

${ }^{30}$ See id. at 840 (O'Connor \& Breyer, JJ., concurring); id. at 868 (Souter, Stevens \& Ginsburg, JJ., dissenting).

31494 U.S. 872 (1990).
} 


\section{Vouchers and Religious Service Providers}

religious authority or dogma." 32 This doctrine of nonintervention in religious disputes, especially significant in matters involving property or employment, has no secular counterpart.

Even the most zealous Neutralists, who may reject one or more of these principles, do not take Neutralism all the way to its logical conclusion. A fully committed Neutralist would include religious piety, along with health, safety, and morals, among the purposes encompassed by government's broad powers to advance the general welfare. The staunchest Neutralists on the bench, however, all adhere to the constitutional requirement that government action must be designed to further secular, not religious, purposes. ${ }^{33}$ Given the Neutralists' rejection of distinctions between religion and other human activities, their unwillingness to include the promotion of religious piety among the legitimate ends of government requires explanation.

In our view, the secular purpose requirement shares an important characteristic with the three, more discrete Separationist principles identified above. ${ }^{34}$ All of these Religion Clause norms primarily involve the practices of institutions, both private and public, rather than the religious beliefs and activities of individuals. Both the requirement of secular purpose and the limitation on religious speech by government prohibit the government as an entity from pursuing distinctively religious ends or engaging in worship. Both the limitation on government funding of religious entities, which places their distinctively religious activities off-limits from public support, and the prohibition on governmental intervention in intra-denominational disputes regulate the relationship between religious institutions and government.

The institutional focus of these norms contrasts markedly with the individualist emphasis that dominates many theories of the Religion

\footnotetext{
32 Id. at 877 .

${ }^{33}$ See, e.g., Mitchell v. Helms, 530 U.S. 793, 802 (2000) (plurality opinion) (citing with approval the longstanding requirement that government action must be designed to achieve secular purposes); Agostini v. Felton, 521 U.S. 203, 211 (1997) (reaffirming proposition that laws must have secular purpose to survive Establishment Clause attack); cf. Edwards v. Aguillar, 482 U.S. 578, 633-34 (1987) (Scalia, J., dissenting) (suggesting that the secular purpose requirement may at times be unworkable, not substantively erroneous, because of problems associated with resort to legislative history to ascertain true legislative purpose). Professor Koppelman's recent defense of the secular purpose requirement, see Andrew Koppelman, Secular Purpose, 88 VA. L. REV. 87 (2002), is thick with important arguments, but it never documents the likelihood of any of the Justices dispensing with the requirement.

34 Those who hold to more robust forms of Separationism accept these three principles, but tend to apply them very broadly, with an eye toward insulating their underlying concerns against erosion. See Lupu \& Tuttle, supra note 13, at 52, 63, 65.
} 


\section{The Journal of Law and Politics}

Clauses. ${ }^{35}$ A number of such theories have as their centerpiece a concern for individual religious conscience. Although matters of conscience were of concern to the Framers and are without question to be taken seriously, they constitute an unstable and conceptually misplaced linchpin for Religion Clause theory. Even if religious conscience was once believed to be a categorically distinctive state of mind, society's contemporary understandings of conscience makes legal distinctions between religious and nonreligious conscience at best highly questionable. ${ }^{36}$

This point, and the rejection of individualist religion as the determinant of constitutional norms, is best reflected in the Supreme Court's recent free exercise jurisprudence. The Court's opinion in Employment Division v. Smith, ${ }^{37}$ which circumscribes the doctrine of free exercise exemptions from general laws, repeatedly emphasizes the chaotic potential of any doctrine that rests on individual assertions of sincere, conscientious objection to compliance with general law. ${ }^{38}$ Writing for the Court, Justice Scalia highlighted a series of problems that such exemption claims present; judges must decide if the claim is religious or not, sincere or insincere, central or peripheral to the faith, and-assuming affirmative answers to all these questions - whether the government's denial of such exemption is justified. ${ }^{39}$ The determinations of religiosity, sincerity, and centrality are inherently

\footnotetext{
35 See, e.g., W. Cole Durham, Jr., Religious Liberty and the Call of Conscience, 42 DEPAUL L. REV. 71 (1992); Rodney K. Smith, Conscience, Coercion, and the Establishment of Religion: The Beginning of an End to the Wandering of a Wayward Judiciary?, 43 CASE W. RES. L. REV. 917 (1993).

${ }^{36}$ For further development of the proposition in text, see Christopher L. Eisgruber \& Lawrence G. Sager, The Vulnerability of Conscience: The Constitutional Basis for Protecting Religious Conduct, $61 \mathrm{U}$. CHI. L. REV. 1245 (1994); Frederick Mark Gedicks, An Unfirm Foundation: The Regrettable Indefensibility of Religious Exemptions, 20 U. ARK. LITTLE ROCK L.J. 555 (1998). Accordingly, the assertions of religious conscience by taxpayers, who complain of being forced to support a religious faith against their will, no longer provide a coherent substantive ground for barring state aid to religious institutions. For functional reasons, however, these assertions should be sufficient to provide a basis for standing to sue; otherwise, the Establishment Clause would remain unenforced. For an opinion recognizing standing of federal taxpayers to sue to enjoin federal expenditures alleged to be in violation of the Establishment Clause, see Flast v. Cohen, 392 U.S. 83 (1968).

37494 U.S. 872 (1990).

38 See id. For examples of where individualized religion and free exercise rights may lead, see Thomas v. Review Board, 450 U.S. 707 (1981) (holding that the Free Exercise Clause requires that members of Jehovah's Witnesses be viewed as having good cause, within the meaning of the unemployment insurance statute, for refusing work on armaments, even though the sect does not hold to the belief, and moral objections to working on armaments do not qualify as good cause) and Frazee v. Illinois Department of Employment Security, 489 U.S. 829 (1989) (holding that the Free Exercise Clause forbids state unemployment compensation board from excluding self-declared Sunday Sabbatarian who belonged to no sect or church from the ranks of those who have good cause to refuse a job requiring Sunday work).

39 See 494 U.S at 885, 886-87. The stringency of the purported standards of justification, pre-Smith, contributed significantly to the difficulties of making consistent and principled decisions about free exercise exemptions.
} 


\section{Vouchers and Religious Service Providers}

subjective, and depend almost entirely upon the word of the claimant. Faced with the boundless possibilities for such exemption claims that individualist religion presents, the Court believed it had only two options: either it could permit continuation of a doctrine that encouraged arbitrary, unprincipled, and potentially discriminatory linedrawing, or it could reject the subjectivist premises on which that doctrine was based. The Court chose the latter, and did so while explicitly affirming institutional possibilities for free exercise norms. ${ }^{40}$

The institutional emphasis of Establishment Clause principles is not yet crystallized in a single, dramatic decision analogous to Smith, but an institutional focus can be discerned from the case law and proves crucial for analysis of the voucher problem. First, the Court has on several occasions held that government may aid individuals in contexts in which it would be unconstitutional for the state to provide direct assistance to religious institutions. For example, in Witters $v$. Washington Department of Services for the Blind, ${ }^{41}$ a unanimous Court upheld a tuition grant to a blind student who wished to study at a Bible college in order to prepare to be a pastor or youth leader in a church; direct grants to Bible colleges themselves for support of instruction in biblical texts, even if linked to a vocational program, would violate the Establishment Clause. ${ }^{42}$

Second, the doctrine of nonentanglement, which reflects values borne out of both Religion Clauses, applies only to government's interaction with religious institutions. In the law of free exercise exemptions, courts viewed

\footnotetext{
${ }^{40}$ Despite the withdrawal in Smith from vigorous review under the Free Exercise Clause, the Court reaffirmed the proposition that courts should not adjudicate questions of "religious dogma" when issues of property or personnel might turn on such questions. Id. at 877. Of course, explicit religious coercion of individuals - forcing them to accept unwanted religious experience-is a core violation of the Free Exercise Clause. See, e.g., Engel v. Vitale, 370 U.S. 421 (1962). This is why forcing individual voucher recipients into a religious experience similarly violates the Free Exercise Clause. See infra notes 77-81 and accompanying text.

41474 U.S. 481 (1986).

42 See id. If taxpayers had a right to insist that government funds never be used to support religious instruction, Witters would obviously be wrong. Yet the Court was unanimous in its support of the result. Professor Choper is one of the few scholars who thinks Witters was incorrectly decided. See JESSE CHOPER, SECURING RELIGIOUS LIBERTY: PRINCIPLES FOR JUDICIAL INTERPRETATION OF THE RELIGION CLAUSES 169 (1995) (arguing that state payment of the grant to Witters has no secular purpose independent of his pursuit of religious employment, and therefore violates the prohibition on using religion as an instrument of civil policy). We think Professor Choper is misguided in application of his principle in Witters; when the state offers to pay for a broad choice of vocational options, it is using the recipient's motivations, not the religious training per se, as an instrument of promoting gainful employment. For other decisions upholding the permissibility of government transfers to individuals, in circumstances in which the government had full awareness of individuals' use of transferred resources for religious purposes, see Rosenberger v. Rector of the University of Virginia, 515 U.S. 819 (1995); Zobrest v. Catalina Foothills School District, 509 U.S. 1 (1993).
} 


\section{The Journal of Law and Politics}

the claimant's sincerity as a proper subject of inquiry, but comparable inquiries into the consistency between the particular practices and doctrines of religious institutions are routinely deemed impermissible. ${ }^{43}$ In the Establishment Clause context, the nonentanglement doctrine historically has been applied only to interactions between government agents and representatives of religious institutions. No comparable concern exists in the relations between government and individuals. Finally, the long line of decisions that bar adjudication by the state of religious questions are also limited to disputes arising within, or involving, religious institutions. ${ }^{44}$

The primary focus of Religion Clause principles on both governmental and religious institutions, rather than on the rights of individual believers ${ }^{45}$ reflects the Constitution's political—not theological or sociologicalconception of religion. Because any definition of religion for legal purposes is a governmental act, the state cannot adopt a particular theological understanding. To do so inevitably privileges one faith tradition over others. Sociological definitions of religion, which depend upon some catalogue of observed commonalities among religious groups, suffer from related defects. Those who create these sociological definitions may identify as religious only those elements that conform to their own preconceptions, and in any event tend only to restate dominant or majoritarian practices. ${ }^{46}$ Like theological

\footnotetext{
43 The line of cases declaring that religious institutions are constitutionally exempt from antidiscrimination claims in connection with the employment of clergy reflects this principle. See, e.g., McClure v. Salvation Army, 460 F.2d 553 (5th Cir. 1972). For discussion of McClure and its progeny, see Lupu \& Tuttle, supra note 13, passim. For an opinion that explicitly ties nonentanglement to both Religion Clauses and to the freedom of religious institutions, see EEOC v. Catholic University of America, 83 F.3d 455, 464-67 (D.C. Cir. 1996).

44 Even in those situations when religious questions arise between individuals, judicial reluctance to decide such matters frequently turns on the issue of coercing individual participation in institutional religious arrangements. For example, the permissible contours of the relationship between the state's family courts and the enforcement of Jewish law was at the center of the controversy over the refusal of some Orthodox Jewish husbands, who sought civil divorce, to deliver to their wives the necessary religious documents to free the wives from the marriage in the eyes of their faith community. For a discussion of this problem, see Tanina Rostain, Note, Permissible Accommodations of Religion: Reconsidering the New York Get Statute, 96 YALE L.J. 1147 (1987). One other potential addition to this list of institutionally focused principles is Larkin v. Grendel's Den, 459 U.S. 116 (1982), which holds that government may not delegate coercive state power to religious institutions. No comparable doctrine exists with respect to private individuals, who, when otherwise properly empowered to act coercively towards third parties, may act out of religious motivations.

${ }^{45}$ As we note above, individual believers are protected by the Free Exercise Clause against direct religious coercion by the state. Individual believers are also protected by the speech and press protections of the First Amendment, see, e.g., Cantwell v. Connecticut, 310 U.S. 296 (1940), as well as by the Equal Protection Clause, pursuant to which any classification of individuals based on their religious beliefs or identity would presumably be suspect.

${ }^{46}$ For a revealing and highly controversial example of a judicial attempt to construct a legal definition of religion out of sociological theories of family resemblances, see Africa $v$. Commonwealth of
} 


\section{Vouchers and Religious Service Providers}

definitions, these too raise serious concerns about religious bias. The bias problem of course can be solved with a purely subjective account of religion making each adherent the definer of her own faith. As the opinion in Smith emphasizes, however, this solution creates its own insoluble problems; it is inherently boundless, and will lead to both unacceptable results in Free Exercise exemption cases, and an understanding of the Establishment Clause that would disable the government from promoting any version of the human good. ${ }^{47}$

Neither theological, sociological, nor subjective individual accounts of religion map with precision onto the reasons for identifying religion as a matter of distinct constitutional concern. The Constitution addresses religion for political, not religious, reasons. Instead of representing an aspect of human life that the state should nourish or suppress, religion demarcates a crucial - indeed, constitutive - boundary of the state's jurisdiction. ${ }^{48}$ The state governs the temporal order, the secular common good. The state has no legitimate authority over the extra-temporal destiny or commitments of its citizens; nor does the state have any religious profession of its own to make. The century just ended provides a stark reminder of the destructive power of

Pennsylvania, 662 F.2d 1025 (3rd Cir. 1981) (holding that prisoner's self-created theology and accompanying practices do not qualify as a religion for First Amendment purposes). See generally Jesse H. Choper, Defining "Religion" in the First Amendment, 1982 U. ILL. L. REV. 579 (1982); George C. Freeman, III, The Misguided Search for the Constitutional Definition of "Religion," 71 GEO. L.J. 1519 (1983); Kent Greenawalt, Religion as a Concept in Constitutional Law, 72 CAL. L. REV. 753 (1984). It is the case, however, that the definition of religion for purposes of qualifying for a tax exemption under $\S$ 501(c)(3) of the Internal Revenue Code has tended to focus on a broad collection of characteristics normally and conventionally associated with religion. For discussion and application of the IRS rules, see Church of the Chosen People v. United States, 548 F. Supp. 1247 (D. Minn. 1982); The Church of the Visible Intelligence That Governs the Universe v. United States, 4 Cl. Ct. 55 (1983). The IRS rules, of course, have no consequence outside the realm of taxation; a failure to qualify under these rules cannot preclude an organization from claiming religious status for other purposes.

${ }^{47}$ The implications of a subjective definition of religion are most easily seen in Free Exercise cases. If individuals are entitled to exemptions from laws that burden their religiously motivated acts, and the individuals are the sole authorities with respect to which of their acts are religious, the result can only be, as the Smith court recognized, jurisprudential chaos. The implications of a subjective view of religion are somewhat more subtle in Establishment Clause cases. If individual perceptions control the definition of religion under the Constitution, then any action of the government that any individual perceives to be religiously motivated - including civil rights laws, environmental laws, or abortion restrictions - may be challenged as a forbidden establishment.

${ }^{48}$ See Carl Esbeck, The Establishment Clause as a Structural Restraint: Validations \& Ramifications, 18 J.L. \& POL. xx (2002); Douglas Laycock, The Benefits of the Establishment Clause, 42 DEPAUL L. REV. 373, 381 (1992) (stating that theology, worship, and religious ritual are outside the jurisdiction of government). 


\section{The Journal of Law and Politics}

any state that makes claims on all aspects of its citizens' lives and sets itself up as an object of worship. ${ }^{49}$

This political understanding of the Religion Clauses prohibits the state from intentionally engaging in, sponsoring, coercing, encouraging, or discouraging religious worship and devotion. Most of the protective quality of this prohibition will run to the benefit of religious institutions, which are typically the organizers, authors, and custodians of worship traditions. ${ }^{50}$ To the extent government policy intentionally aims at the worship practices of individuals, however, the prohibition applies with equal force. For example, the practice of state-sponsored prayer in public schools, held unconstitutional by the Supreme Court, ${ }^{51}$ constitutes a dual violation of the Religion Clauses. State-composed prayer involves government officials in forbidden authorship of religious ritual, ${ }^{52}$ and recital of such prayer in public schools coerces students either to engage in worship, or publicly signal their unwillingness to do so.

\section{B. The Reconsidered Religion Clauses Applied to Vouchers}

If, as we claim, the state must leave in private hands the experience of devotion to ultimate authority or concern, the state may not pay for such experience in non-voucher programs. ${ }^{53}$ To do so is to violate the Madisonian injunction against using faith as "an instrument of civil policy," 54 and to put

\footnotetext{
${ }^{49}$ See HANNAH ARENDT, ORIGINS OF TOTALITARIANISM (1951); for further discussion of this theme, see Lupu \& Tuttle, supra note 13, at 83-84.

${ }^{50}$ See, e.g., Church of the Lukumi Babalu Aye, Inc. v. Hialeah, 508 U.S. 520 (1993) (holding that the city may not single out worship practice of animal sacrifice for disfavored treatment). Although the peyote use in Employment Division v. Smith, 494 U.S. 872 (1990), led to individualized legal consequences, the factual setting of the use of the substance was also a worship ritual practiced by an organized religious community.

51 Abington Sch. Dist. v. Schempp, 374 U.S. 203 (1963); Engel v. Vitale, 370 U.S. 421 (1962).

52 The authorship, recital, or promotion of prayer by military chaplains may be distinguished, and found constitutionally acceptable, on the theory that the institution of the chaplaincy is necessary to protect the free exercise rights of military personnel, forced by their orders to be away from their civilian faith communities. See Katcoff v. Marsh, 755 F.2d 223 (2d Cir. 1985). Administering an institution like the chaplaincy without running afoul of the Constitution may not be easy. See, e.g., Adair v. England, 183 F. Supp. 2d 31 (D.D.C. 2002) (ruling on some aspects of a complaint that the Department of the Navy discriminates against non-liturgical Christian Navy chaplains).

53 Agostini v. Felton, 521 U.S. 203, 228-29 (1997); Mitchell v. Helms, 530 U.S. 793, 840 (2000) (O'Connor, J., concurring); Freedom from Religion Found., Inc. v. McCallum, 179 F. Supp. 2d 950 (W.D. Wis. 2002). The state, however, may pay for a secular portion of such programs, assuming the secular and the religious can be separated for accounting purposes without excessive state monitoring of religious institutions. See Lupu \& Tuttle, supra note 13, at 84-88.

54 James Madison, Memorial and Remonstrance Against Religious Assessments, in JAMES MADISON, WRITINGS 29 (Jack N. Rakove ed., 1999). For a creative and important recent effort to tie Madisonian concerns to the problem of the constitutionality of vouchers, see Vincent Blasi, School Vouchers and
} 


\section{Vouchers and Religious Service Providers}

the state, as payor, in a position to dictate the content of faith. Voucher programs, however, may disconnect the state from the worship experience in constitutionally sufficient ways. The core question for any voucher program, therefore, is the extent to which it is reasonable to impute to the government the recipient's religious experience, if any, arising out of that program. When the design of the program creates substantial pressures on recipients to undertake religious experience, the program as a whole may violate the Establishment Clause. ${ }^{55}$

To be true to the unbroken path of Establishment Clause adjudication over the past forty years, inquiry into the existence of such pressures must extend beyond the narrow, often impenetrable question of whether the state intends to promote religious experience. Ever since the Supreme Court's decision in 1963 in School District of Abington v. Schempp ${ }^{56}$ the reigning approach to Establishment Clause questions has focused upon the state's responsibility for the religious effects of policies enacted to achieve secular goals. ${ }^{57}$ Though only hinted at in Everson v. Ewing Township, ${ }^{58}$ this inquiry surfaced in the 1960 's in the context of challenges to Bible reading in public schools ${ }^{59}$ and the loaning of textbooks from the state to sectarian schools; ${ }^{60}$ took on a crucial role in the 1970's in Lemon v. Kurtzman ${ }^{61}$ and its progeny, ${ }^{62}$ regarding state assistance to sectarian schools; continued into the 1980's in cases involving state endorsement or support for religious messages; ${ }^{63}$ remained vital in the 1990 's in cases involving graduation prayer, ${ }^{64}$ aid to sectarian schools, ${ }^{65}$ and religious gerrymandering; ${ }^{66}$ and lives on in the 2000's in cases concerning

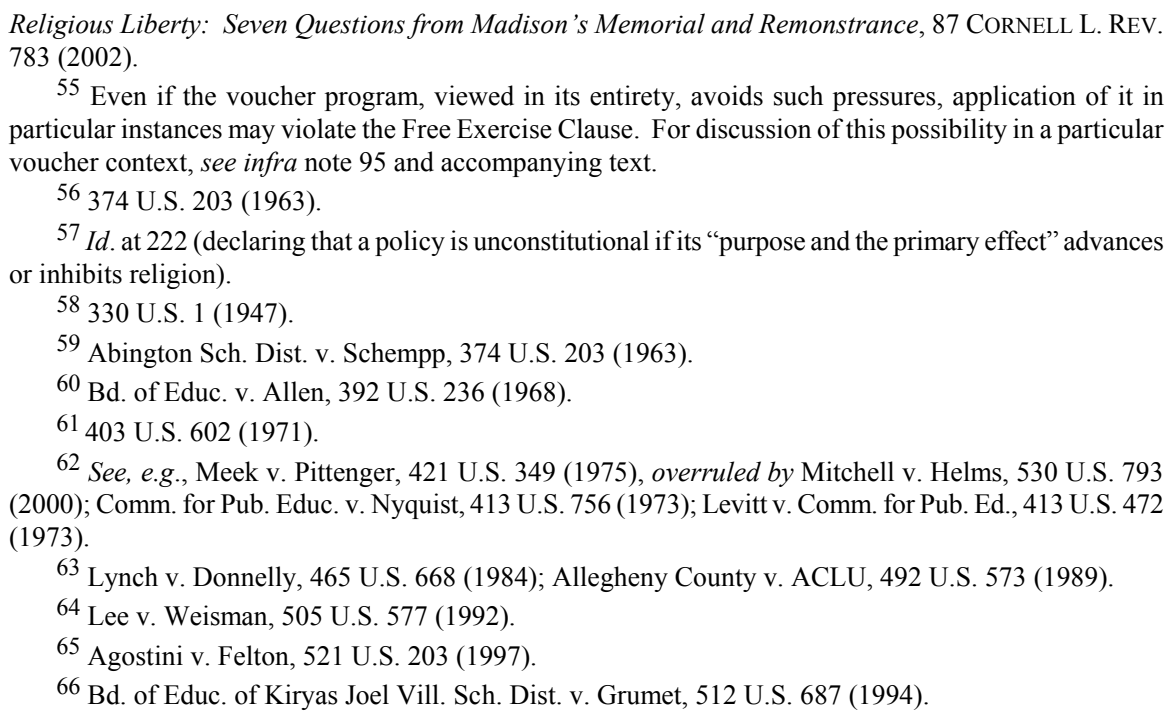




\section{The Journal of Law and Politics}

governmental financial support for religion ${ }^{67}$ as well as cases involving statebacked religious speech in the public schools. ${ }^{68}$

Moreover, the precise formulation and analytical focus of the inquiry into effects has changed somewhat over the past forty years. Those changes serve only to buttress our view that the relevant question in voucher cases is not about an imposition on taxpayers, who of course will be obliged to pay for religious experience whether or not recipients have meaningful choices among providers. Instead, the question of forbidden effects in voucher cases is about the state's role in creating pressures and incentives toward religious experience in ways that make it more likely to be undertaken than would have been the case in the absence of the voucher program.

The concern for impermissible state pressure in the direction of religious commitment is hardly a new theme in Establishment Clause adjudication. Indeed, this was the analytical centerpiece in Abington School District v. Schempp, ${ }^{69}$ in which the question, as framed by the Supreme Court, was whether the practice of Bible reading to begin the public school day had the "primary effect" 70 of advancing or inhibiting religion. In later decisions, such as Board of Education v. Allen ${ }^{71}$ and Lemon, ${ }^{72}$ the language of the effects test remained the same, but the focus seemed to shift sharply toward the probability that the state had become engaged in financing religious experience. Most recently, the rise of both the endorsement and coercion tests have returned the question of forbidden effects to the government's complicity in religious experience. The emphasis on effects in County of Allegheny v. ACLU, ${ }^{73}$ in which a Court majority adopted Justice O'Connor's proposed endorsement test, is focused upon the perception of reasonable observers that the state has, by its message, created religious insiders and outsiders, not on the undisputed fact that the state is spending taxpayers' money to display religious messages. Moreover, Lee v. Weisman ${ }^{74}$ the graduation prayer decision, emphasizes the constitutional impermissibility of state-created compulsion - in fact, even if not in law - to participate in prayer

\footnotetext{
${ }^{67}$ Mitchell v. Helms, 530 U.S. 793 (2000).

${ }^{68}$ Santa Fe Ind. Sch. Dist v. Doe, 530 U.S. 290 (2000).

69374 U.S. 203 (1963).

${ }^{70} I d$. at 222 . The Abington court also considered whether the Bible reading practice had a secular purpose, but it did not limit its inquiry to questions of governmental intention.

71392 U.S. at 243.

72403 U.S. at $612,613$.

73492 U.S. 573 (1989).

74 505 U.S. 577 (1992).
} 


\section{Vouchers and Religious Service Providers}

as the price of receiving the benefit of participation in commencement. ${ }^{75}$ And this thematic emphasis is reinforced in the Court's most recent majority opinion in an Establishment Clause controversy, Agostini v. Felton, ${ }^{76}$ in which the Court asked whether the effects of the state's policy included "a financial incentive to undertake religious indoctrination."77

Thus, whatever the Establishment Clause context, and even as the particular formulation of the doctrine of forbidden religious effects has taken on more complex coloration, the Supreme Court has consistently focused on the obvious and foreseeable religious consequences of state policy, and has turned in particular toward the effects on the targets or recipients, rather than the tax-paying financiers, of religious experience. This attention to those whom the state may be effectively indoctrinating is a crucial reminder that, however laudable and secular the state's ultimate ends may be, the state may not now, as in Madison's time, exploit religious devotion for civic, governmental purposes.

Erroneously and unhelpfully focused on the rights and interests of taxpayers rather than the experiences of recipients, voucher proponents and opponents alike take a conceptually impoverished view of whether the government should be held constitutionally responsible for the religious consequences of voucher programs. Both groups describe the set of relationships involved in voucher programs as a straight line running from government to recipients and then to service providers. For proponents of vouchers, the intermediary position of recipients decisively breaks the connection between government and service provider. Opponents highlight the direct line between the source and eventual destination of the money and treat the recipient's place along that line as constitutionally irrelevant. Neither view captures the experience of recipients in ways that illuminate whether the state should be held accountable for religious content.

As we conceptualize vouchers, the image of a triangle better reflects the constitutionally significant relationships. Each of the three actors in these programs - government, voucher recipients, and service providers - relates to the other two in ways that highlight the relevant features of voucher schemes.

\section{The relationship between voucher recipients and the state}

\footnotetext{
75 See id. at 593-94.

76521 U.S. 203 (1997). The more recent decision in Mitchell v. Helms, 530 US. 793 (2000), did not produce a majority opinion, so Agostini remains the last Establishment Clause case to do so.

77521 U.S. at 231.
} 


\section{The Journal of Law and Politics}

We begin with the relationship between government and voucher recipients. This relationship involves three elements important for our analysis. First, recipients may or may not be free to choose whether to use the voucher at all. Second, recipients select from the universe of eligible providers, but the range of choice varies among programs. Together, this pair of choices bears on the degree of freedom the recipient exercises with the voucher, and thus the extent to which the government can fairly be said to have "steered" the recipient toward any particular service. Third, government creates such programs in order to generate specific outcomes for beneficiaries - nutrition, shelter, education, sobriety, or health, among others. The kind of outcome the government desires from the program also bears on the extent to which it can be held accountable for any religious experience associated with that outcome.

The relationships between government and recipients in some voucher programs offer little reason for constitutional concern. For example, consider a program — call it "Book Stamps" - in which the government provides each person with a $\$ 20$ voucher, redeemable for books at any place of business where books are regularly sold. The program is designed to promote literacy, but of course has the side effect of subsidizing publishers and booksellers. Such a program would predictably lead to the acquisition of Bibles and other devotional materials, just as it would lead to the purchase of self-improvement books, pulp mysteries, and steamy romance novels.

Although it is completely foreseeable that recipients of "Book Stamps" may purchase religious tomes, the particulars of the recipient-government relationship in the program render wholly unreasonable any claim that the government is constitutionally accountable for religious experiences that recipients might derive from the program. First, recipients are not compelled to redeem the vouchers; government is not requiring its citizens to buy books, and, despite what we scholars may think, books are hardly necessities of life. Second, recipients have a staggeringly broad range of choices among books, including a virtually unlimited number of nonreligious options. Third, the

government is indifferent to the content of books acquired. Its purposes of fostering literacy and aiding the book industry are fully served whether recipients read religious or nonreligious books, so long as recipients buy and read. The reader's response to the literature - titillation, transformation, or edification - is a matter entirely apart from the government's purposes in the "Book Stamps" program.

Other voucher programs will have quite the opposite effect. Such programs effectively steer recipients to particular service providers and promote outcomes that are inseparable from religious experiences. Consider 


\section{Vouchers and Religious Service Providers}

here the example of vouchers for service at drug treatment programs offered to criminal defendants as alternatives to incarceration for drug crimes. The government's ostensible purposes in such a program include rehabilitation of drug-dependent defendants and, perhaps, relief of pressure on overcrowded prison facilities. ${ }^{78}$ Assume that in a particular community, the only available programs at which vouchers can be redeemed are infused with methods of faith-based character transformation. ${ }^{79}$

The three aspects of the government-recipient relationship that determined the validity of "Book Stamps" all point in the opposite direction in this case. First, recipients are powerfully constrained in their choice of whether or not to avail themselves of rehabilitation services; 80 the only alternative to voucher redemption is prison time. Second, the choice among providers is limited to religious options; although recipients have a choice to make, no providers offer nonreligious treatment services. Third, in marked contrast to "Book Stamps," the government's purpose in this case is inseparable from the religious transformation promised by these providers. What government seeks in such programs is not limited to the cessation of drug-related criminal behavior; rather, by directing recipients ${ }^{81}$ into comprehensive treatment regimens, government is trying to effect fundamental changes of character, outlook, and associational preferences. ${ }^{82}$

These two paradigmatic voucher programs exist at either extreme of a constitutional spectrum. Most voucher cases, of course, fall between the

\footnotetext{
${ }^{78}$ For discussion of these programs, see Peggy Fulton Hora et al., Therapeutic Jurisprudence and the Drug Treatment Court Movement: Revolutionizing the Criminal Justice System 's Response to Drug Abuse and Crime in America, 74 Notre Dame L. ReV. 439 (1999); Developments in the Law: Alternatives to Incarceration For Drug Abusing Offenders, 111 HARV. L. REV. 1898 (1998). See also Office of National Drug Control Policy Fact Sheet, Drug Treatment in the Criminal Justice System (March 2001), available at http://www.whitehousedrugpolicy.gov/publications/pdf/94406.pdf).

${ }^{79}$ In Freedom from Religion Foundation, Inc. v. McCallum, 179 F. Supp. 2d 950 (W.D. Wis. 2002), Judge Crabb suggested that probation officers might be pushing defendants into a single, faith-intensive provider, because it was the only provider in the community offering a 12-month, residential program for substance abuse.

${ }^{80}$ Indeed, in some states, drug treatment is mandatory; defendants have no option to select ordinary incarceration. See, e.g., Robert Granfield et al., An Evaluation of the Denver Drug Court: The Impact of a Treatment-Oriented Drug Offender System, 20 LAW \& POL'Y 183 (1998).

81 People in these circumstances are in a complex, mixed role of criminal defendants, service recipients, and agency clients.

${ }^{82}$ Not all court-referred programs for substance abuse have each of these features in equal measure. For a general description of drug treatment courts, see Defining Drug Courts: The Key Components, Drug Courts Program Office, U.S. Dept. of Justice (January 1997), available at http://www.ojp.usdoj.gov/dcpo/Define. For a description of the comprehensive therapeutic goals implicit in the drug court movement, see Hora, et. al., supra note 78. For a critique of the comprehensive therapeutic goals of drug courts, see Richard Boldt, Rehabilitative Punishment and the Drug Treatment Court Movement, 76 WASH. U. L.Q. 1206 (1998).
} 


\section{The Journal of Law and Politics}

extremes, and thus present more difficult questions of constitutionality. Consider, for example, the well-established program of federal block grants to states and localities for the payment of child care expenses of low-income families. ${ }^{83}$ Families may use child care vouchers to pay child care centers operated out of homes ("home-based care"), religious providers, nonreligious providers in institutional settings, and even their own relatives. ${ }^{84}$ In fact, almost as many children in the program are in relative care and home-based care as are in day care centers. ${ }^{85}$ Like our hypothetical "Book Stamps" program, the child care program will inevitably and foreseeably include religious content; some relatives, some home-based providers, and most religious institutions will engage in religious instruction while providing the care. The question is whether this religious activity by providers impairs the constitutional validity of the child care program.

To answer this question, we return to the three issues identified earlier. First, with respect to the choice of using the voucher or not, the child care services must be seen in the broader context of public welfare programs. Some families who participate in the program are recipients of Temporary

\footnotetext{
83 Child Care and Development Block Grant Act of 1990, 42 U.S.C. § 9858n(2) (1994 \& Supp. V, 1999). The Child Care Development and Block Grant is one of four federal child care development programs that were folded into the Child Care Development Fund by the welfare reform legislation of 1996, which goes under the title of the Personal Responsibility and Work Opportunity Reconciliation Act of 1996 (P.L. 104-193). See http://www.os.dhhs.gov. Some low-to-middle income families are eligible for child care vouchers even if they are not eligible for welfare payments. See 42 U.S.C. § 9858(n)(1)(B) (making eligible for child care assistance, at the state's discretion, an individual under the age of 13 "whose family income does not exceed 85 percent of the State median income for a family of the same size."). Moreover, former recipients of Temporary Assistance for Needy Families remain eligible for child care vouchers even after their total 60 -month eligibility for cash benefits has expired. Personal Responsibility and Work Opportunity Reconciliation Act of 1996 (P.L. 104-193), § 908(b).

${ }^{84}$ The relevant statutes also permit the use of contracts as well as vouchers, or "certificates," with child care providers, and authorize use of certificates at sectarian providers. With respect to the Child Care and Development Block Grant, see 42 U.S.C. § 9858(n), which expressly provides that "[n]othing in this subchapter shall preclude the use of such certificates for sectarian child care services ... if freely chosen by the parent." Id. With respect to Temporary Assistance to Needy Families, see $\S \S 604 \mathrm{a}(\mathrm{a})(2), 604 \mathrm{a}(\mathrm{c})$. In cases of grants and contracts, the use of government funds for sectarian worship and instruction is statutorily forbidden. 42 USC $\S 604 a(j)$ (2001). For further discussion of the child care program, see Douglas Besharov \& Nazanin Samari, Child Care Vouchers and Cash Payments, in VOUCHERS AND THE Provision of PUBlic SERVICES, supra note 6, at 195-203.

85 The 1999 Report of the Child Care Bureau of the U.S. Department of Health and Human Services breaks down the distribution of children in all types of care financed by the Child Care and Development Fund, and shows that the nationwide average is $56 \%$ of children in day care centers, with the rest spread among the child's home, home of a relative, or family-based care ("group home'). 1999 Report of the Child Care Bureau of the U.S. Department of Health and Human Services, available at http://www.acf.dhhs.gov/programs/ccb/research/99acf800/list.htm (last updated Mar. 11, 2002). The 56\% figure is a drop from the early 1990's, when closer to two-thirds of child care financed through the Child Care and Development Block Grant Act took place in centers rather than in homes. WILLIAM T. GORMLEY, JR., EVERyBody's ChILdREN: ChILd CARE AS A PUBlic PROBlem 127 (1995).
} 


\section{Vouchers and Religious Service Providers}

Assistance to Needy Families with Children ("TANF"); 86 these families, many of which are headed by a single parent, are under a statutory duty to engage in work as a condition of receiving TANF benefits. ${ }^{87}$ If they do engage in work away from their children, these parents are legally compelled to place their children in some form of child care during the work day. ${ }^{88}$ Other low-income families, eligible for child care vouchers, do not receive TANF or any other public assistance that mandates work efforts; ${ }^{89}$ nevertheless, economic necessity may motivate the parents in such families to seek work outside the home. If they do, the law of child neglect applies to them just as it does to the TANF families. Thus, for virtually all families eligible for child care vouchers, a combination of legal norms and economic circumstances pushes them to use the vouchers.

Second, at least in theory, child care voucher recipients enjoy a very broad choice among providers. In many locales, there is a broad array of child care providers, including for-profit and not-for-profit, religious and nonreligious, institutional and home-based. For those with family members nearby and willing to care for children, this variety is even greater. It is true that most families receiving vouchers for child care are under considerable pressure to use them, and many child care centers have long waiting lists. Nevertheless, the range and variety of providers suggests that the government should not

\footnotetext{
86 The program for Temporary Assistance to Needy Families ("TANF") is part of the federal welfare reform legislation enacted in 1996, as part of the Personal Responsibility and Work Opportunity Reconciliation Act of 1996 (P.L. 104-193). The TANF program replaced Title IV-A of the Social Security Act (Aid to Families with Dependent Children), and does not have the characteristics of its predecessor as a legal entitlement. 42 U.S.C. $§ 604$ a et seq. (1996). TANF expires this year and is now being considered for reauthorization. For a more complete and thorough description of the TANF program, see Department of Health and Human Services, Administration For Children and Families, Office of Family Assistance, Helping Families Achieve Self-Sufficiency: A Guide on Funding Services for Children and Families Through the TANF Program, available at http://www.acf.dhhs.gov/programs/ofa/funds 2 .htm (last visited April 21, 2002).

87 Social Security Act, 42 U.S.C. $§ 602$ (2002) (obliging participant states to require parents or caretakers of children to participate in work within 24 months or once the state determines the parent or caretaker is ready for work, whichever is earlier).

88 The legal compulsion flows from laws prohibiting the neglect of minor children. See, e.g., CAL. WELF. AND INST. CODE $§ 300$ (b) (West 1998) (placing under jurisdiction of the juvenile court any person under the age of 18 whose home is an unfit place for him or her by reason of neglect.) Severely neglected children may be removed from the physical custody of their parents or guardian. Id. at $\S 361$. See generally Michael Wald, State Intervention on Behalf of "Neglected" Children: A Search for Realistic Standards, 27 STAN. L. REV. 985 (1975).

${ }^{89}$ Low-income families may receive federally subsidized child care assistance even if they are not TANF beneficiaries. See State Policy Documentation Project - Findings in Brief: Child Care Assistance, available at www.spdp.org/tanf/childcare/childcaresumm.htm (last updated January 2, 2001).
} 


\section{The Journal of Law and Politics}

ordinarily be held responsible for the religious content that might be offered by some. ${ }^{90}$

Third, the government's interest in child care, and its relation to religious development, must be measured in light of the particulars of the program. Were the providers limited to facilities licensed on the basis of their capacity to nurture character and intellect, one might say that the program was analogous to drug treatment in its concern for the development of the whole person. But this is not the character of the existing child care program; $;{ }^{91}$ by including home-based and relative care in the mix of eligible providers, and by the omission of any requirement of professional training for child care workers, the program's child-based goals are little more than the physical health and safety of children.

The child care program thus stands somewhere between the two extremes on the spectrum, but it seems considerably closer to our imaginary "Book Stamps" program. Although the recipients may be under considerable legal or economic compulsion to use child care services, the mix of potential providers is sufficiently wide to preclude any reasonable claim that the government is steering recipients' children into programs of religious formation. This judgment is further reinforced by government's limited ends in this child care program. The goal is to avoid physical neglect of children while parents go out to work, rather than to promote a richer vision of child development, whether religious or secular.

Although the child care program on its face appears to be constitutionally acceptable, it is not hard to imagine particular circumstances in which this or a similar program could be problematic. Consider those TANF beneficiaries

\footnotetext{
${ }^{90}$ Recipients may have more control over the content of communications to their children in situations in which relatives are the caregivers, although even in that situation the control is incomplete, and the care provided is a package of all that a particular care provider will offer. Nevertheless, recipients presumably can acquire a reasonable quantum of information about religious communications at the child care providers they are considering.

${ }^{91}$ This is reflected both by the omission of any federal requirement that voucher providers be licensed, see Besharov \& Samari, supra note 84 , at 196, and by the stated statutory purposes of the Child Care Development and Block Grant Act of 1990, which include 1. allowing state flexibility in developing programs that meet the needs of parents and children; 2. promoting parental choice to make child care decisions best suited to their family; 3 . encouraging states to provide better information about child care; 4 . assisting states to provide child care to parents seeking to escape welfare dependency; and 5. assisting states in implementing their own health and safety regulations. 42 U.S.C. $\$ 9858$ (a). None of these commits the federal government to any version of the well-being of children. Of course, some child care providers will be deeply committed to child development, religious and otherwise. See Mary M. Bogle, $A$ Survey of Congregation-Based Child Care in the United States, in SACRED PlaCES, CIVIC PuRPoSes: Should Government Help Faith-BASEd Charity? 220, 229 (E.J. Dionne \& Ming Hsu Chen eds., 2001) ("What is most evident is that the purposes of education/enculturation and evangelism (for Christian churches) are rising with the tide of institutional interest [in child care].")
} 


\section{Vouchers and Religious Service Providers}

who live in an area in which they have no relatives willing or able to engage in child care, no home-based care is available, and day care centers are both scarce and, without exception, religious in character. In such a market, our initial appraisal is that government is steering such recipients to place their children in a religious environment. They will lose their TANF benefits if they do not seek work and place their children in some form of approved child care, and their choices for such care appear to force them in the direction of a religious placement.

The dynamic or static qualities of the provider market, however, are crucial in the attempt to measure the degree of steering the program is likely to produce. Where barriers to provider entry, including licensing requirements and start-up costs, are substantial, a conclusion of impermissible steering might seem particularly warranted. In practice, however, neither of these barriers to entry is especially high in the child care context. ${ }^{92}$ Although some TANF recipients may have difficulty finding acceptable, nonreligious child care in the short term, the government should not be charged with an Establishment Clause violation for steering them into a religious placement for child care. First, such a problem is not likely to be a common feature of markets for child care. The available evidence suggests that the supply of home-based care is roughly equal to the supply of institutional care, religious or otherwise. ${ }^{93}$ Because, at any given time and place, a variety of religious and nonreligious options for child care is likely to exist, government cannot fairly be held responsible for encouraging parents to select religious environments for child care. Second, even if this mix is not reflected at a given moment in a particular locale, the market is likely to be sufficiently fluid that nonreligious alternatives will soon appear. During the time that only religious alternatives are available, TANF recipients may find little practical choice but to enroll their children in such a program, but will be free to shift to a more acceptable one when it becomes available. ${ }^{94}$

More significantly, the federal statute precludes the denial of TANF benefits to recipients who refuse work because of the "unavailability of appropriate child care within a reasonable distance from the individual's

\footnotetext{
92 See Besharov \& Samari, supra note 84, at 204.

${ }^{93}$ Id. at 206. See also Table 6, 1999 Report of the Child Care Bureau of the U.S. Department of Health and Human Services, supra note 85 (documenting that close to half of the children in governmentsubsidized child care were in home-based settings).

${ }^{94}$ We recognize that the usual market problem for recipients is that of finding spaces in good, existing programs, and that shifting from one care provider to another may be difficult, and may be made more so by the effects on the child of the dislocation.
} 


\section{The Journal of Law and Politics}

home or work site." 95 Although the statute places the burden of persuasion on this point on the recipient, any recipient who is compelled to use a religious child care provider may have a valid legal objection under the TANF statute and state regulations implementing it, as well under the Free Exercise Clause. ${ }^{96}$ Nevertheless, given this overall set of program features, the argument that government is violating the Establishment Clause-which, unlike the Free Exercise Clause, operates at wholesale, not retail-by pushing the children of voucher recipients into religious experience is unpersuasive.

Suppose, however, that the federal child care program excluded relative care and home-based child care, thus limiting the class of eligible providers to licensed institutions. Many child welfare advocates have supported the preference for professionalized child development centers implicit in such a limitation..$^{97}$ Consistent with this preference, suppose further that the federal program imposed standards of cognitive learning, character formation, and socialization skills upon eligible providers.

If, in such a program, religious institutions were included among the ranks of eligible providers, the scheme would raise more serious Establishment Clause concerns than the existing arrangements. ${ }^{98}$ The hypothetical revisions to the child care program have no impact on our first inquiry, the question of whether the recipient is under some compulsion to use the provided service. With respect to the second inquiry, however, concerning the breadth of the provider class from which recipients may choose, the changes are dramatic.

\footnotetext{
9542 U.S.C. $\S 607(\mathrm{e})(2)(\mathrm{A})$ (1994). Each state has its own standards of appropriateness. None mention "religious appropriateness," although a number of state policies do refer to a child's "special needs," which might include religious needs. For a full compilation of state policies on appropriateness, see State Policy Documentation Project, The TANF Child Care Protection: Families Covered As of October 1999, available at www.spdp.org (last updated January 11, 2001) (copy on file with authors). When child care placements are with relatives, recipients have the arguably stronger option of complaining about their "unsuitability," as defined by state law and regulation. Unsuitability definitions range widely among the states, and none specifically mention religious environment as an element of suitability. See id.

96 If the TANF system were to exclude the religious content of a particular child care provider's program from the grounds justifying a finding of nonsuitability, still-vital decisions under the Free Exercise Clause would provide substantial grounds for constitutional challenge. See Sherbert v. Verner, 374 U.S. 398 (1963) (holding that the Free Exercise Clause forbids state from excluding religious reasons for unavailability for work from good cause determination in the administration of unemployment insurance scheme). The Supreme Court's decisions in Pierce v. Society of Sisters, 268 U.S. 510 (1925), and Wisconsin v. Yoder, 406 U.S. 205 (1972) (holding that Free Exercise Clause requires exemption from affirmative duty of parents to send children to accredited school until the children reach the age of 16) would clearly support the extension of Sherbert to the child care context.

97 See, e.g., Ellen Kisker \& Rebecca Maynard, Quality, Cost, and Parental Cost of Child Care, in THE ECONOMICS OF CHILD CARE 130 (David Blau ed. 1991). The idea that licensed child care centers are necessarily better for child development is questioned in Besharov \& Samari, supra note 84, at 206-10.

98 The imposition of state licensing standards on religious providers also raises questions about the government-provider relationship, which we consider immediately below.
} 


\section{Vouchers and Religious Service Providers}

The exclusion of home-based and relative care does more than just limit the quantity of the recipient's options. The limitation of the program to institutional settings also decreases the dynamism in the market, because the costs of creating a new home-based care facility are likely to be far lower than the comparable costs to institutions, which typically involve the reconfiguration of physical space and the employment of child care workers. ${ }^{99}$ Although these considerations are not dispositive of the constitutional issues - in any particular market, there may be a sufficiently broad array of institutional choices, secular as well as religious - the limitation to institutional providers increases the plausibility of a claim that government has steered recipients to religious child care centers.

Moreover, the imposition of stringent child development standards in our hypothetical revision further aggravates the constitutional risk. The government is insisting upon much more than health and safety for the affected children; its purposes now include the far more ambitious goals of intellectual stimulation and moral formation. By including these objectives, the question of the government's responsibility for the religious content of providers' programs becomes more complicated than under the existing scheme.

Contrast the shape of this hypothetical child care program with the two paradigm cases identified above, "Book Stamps" and mandatory drug treatment. "Book Stamps" involved no compulsion to participate, abundant choices of book providers, and government indifference to book content; mandatory drug treatment involved the opposite conditions - strong compulsion to participate, options limited to religious providers, and government focus on robust changes in recipients' character. Our revised child care program certainly contemplates deeper individual transformation than "Book Stamps" intends, but the compulsion to participate falls between the two poles, and the mix among providers is variable and may, in any particular community, include either a very high or a very low percentage of religiously oriented providers. The revised program thus presents a close case, one in which the placement of the burden of persuasion may loom large. For now, we assert only this: where recipients are effectively compelled to participate in a service program, religious providers dominate a particular market, and the government insists on significant character development as an

\footnotetext{
99 The costs of providing such services at institutions are relatively low for child care compared to other services, but home-based care remains cheaper than institutional care, in part because most states exempt all home-based care from licensing requirements. See Department of Health \& Human Services Office of Inspector General, States' Child Care Certificate Systems: An Early Assessment of Vulnerabilities and Barriers (Feb. 1998), at 14.
} 


\section{The Journal of Law and Politics}

intended outcome of the service, the government is presumptively responsible for any religious experience that is generated by the program.

\section{The Relationship Between Providers and the State}

Constitutional debates about voucher programs have focused almost exclusively on the relationship between recipients and the state. Such focus, however, misses another relationship - that between providers and the statenecessary for adequate constitutional analysis of vouchers. In voucher programs, the constitutionally significant interactions between providers and the state can be divided into two categories.

First, government policies will have a profound effect on both the number and the mix of providers participating in any voucher program. The criteria that state officials use to select eligible providers might be broad, inviting participation by most providers of a given service, or quite narrow, excluding all but a few. In some cases, the criteria may skew the mix toward religious providers. Similarly, the amount paid per recipient might be sufficient to induce a wide range of providers to participate, or it might operate to deter all but providers willing to render services for the lowest cost. ${ }^{100}$ With respect to some types of service, religious providers may be disproportionately represented among low cost providers. By effectively controlling the mix of service providers, state policies relating to eligibility criteria and voucher amount inevitably affect the extent to which voucher recipients are steered into religious experiences.

Second, all voucher programs involve some degree of government monitoring of service providers. This monitoring typically includes financial audits, but may also encompass evaluations of the content and quality of the service provided. As those familiar with the law of the Establishment Clause know, government monitoring of religious institutions sometimes creates constitutionally troublesome interactions. ${ }^{101}$ Although financial audits that examine only whether voucher funds have been used for the intended services

\footnotetext{
100 Professor Minow has suggested that school voucher amounts usually "approximate[] the tuition level set by parochial schools... [which] reflects subsidies from other sources," including lower overhead costs due to longstanding ownership of school buildings or subsidies from endowment or other private contributions. Martha Minow, Reforming School Reform, 68 FordHAM L. REV. 257, 262 (1999). We discuss the implications of voucher amounts for the Cleveland school case in Part III, infra.

101 These interactions might raise non-Establishment concerns, see Lemon v. Kurtzman, 403 U.S. 602, 627 (1971) (invalidating program of aid to private, sectarian schools because state monitoring to ensure that the aid would not support religious teaching creates "excessive entanglement" between state agents and church officials), as well as Free Exercise issues, see NLRB v. Catholic Bishop of Chicago, 440 U.S. 490 (1979). We elaborate on the place of entanglement concerns in existing Separationist principles in Lupu \& Tuttle, supra note 13, at 59-62.
} 


\section{Vouchers and Religious Service Providers}

are ordinarily not problematic, evaluations of service content and quality create the possibility of what the Supreme Court has identified as forbidden entanglements. ${ }^{102}$ In non-voucher programs, the government is forbidden from financing religious teaching or worship. Accordingly, the entanglement problem raised by such programs is stark; if government finances the secular portion of a program run by a faith-intensive organization, the state must monitor the conduct of personnel and the content of materials in the program in ways that are highly likely to produce interactions over the meaning and role of faith in the service provided. ${ }^{103}$ The state's agents may overzealously bully the institution in inappropriate ways; alternatively, the agent may be corrupted by entreaties from the institution that she overlook religious content in the program.

In voucher cases, however, the inclusion of providers with intensely religious services in the overall mix creates the possibility of new and subtle entanglement problems. First, some voucher programs include the practice of provider reports to government agents on the progress of recipients toward program goals. In cases of wholly secular providers, such reports are routine and unexceptional. If, for example, those charged with drug crimes are being provided with treatment rather than being incarcerated, it makes complete sense for drug court personnel to monitor whether defendants are cooperating with, and making progress in, the treatment regime. ${ }^{104}$ When, however, the provider depends heavily on faith-based methods, state monitoring of progress takes on an entirely different character. Progress reports may recite the extent to which participants have accepted or surrendered to religious faith, and state intervention in the program may take the form of tinkering with its faith-based methods or the relationship between these methods and others. Indeed, in voucher programs, in sharp contrast to non-voucher programs, state monitors may have incentives to persuade providers to increase the faith content in their methods rather than tone them down or segregate them.

\footnotetext{
102 The factors utilized by courts to evaluate entanglement concerns include "the character and purposes of the institutions that are benefited, the nature of the aid that the State provides, and the resulting relationship between the government and religious authority." Agostini v. Felton, 521 U.S. 203, 232 (1997) (quoting Lemon, 403 U.S. at 615).

${ }^{103}$ For a helpful discussion of this problem, see Michele Estrin Gilman, "Charitable Choice" and the Accountability Challenge: Reconciling the Need for Regulation with the First Amendment Religion Clauses, 54 VAND. L. REV. at notes 368-384 and accompanying text (forthcoming, 2002).

${ }^{104}$ See Hora, et al., supra note 78, at 473-80; Defining Drug Courts, supra note 82, at 10-18; see also Michael C. Dorf \& Charles F. Sabel, Drug Treatment Courts and Emergent Experimentalist Government, 53 VAND. L. REV. 831 (2000).
} 


\section{The Journal of Law and Politics}

A second, and rather different form of entanglement may arise in the voucher context. Concerned about the overall mix of religious and nonreligious sites, rather than the degree of religiosity in any given provider, state monitors may try to persuade some, though not necessarily all, providers to tone down their religious content, or to make it an optional part of the service, as a way of expanding the number of sufficiently secular alternatives. In this setting, in which certain amounts and distributions of religious experience among providers may properly be tolerated by the government, the problem of agent bias looms especially large; monitors may perceive a greater degree of sectarianism in unfamiliar faiths.

The existing child care program, and hypothetical variations on it, helps to illustrate many of the ways in which aspects of the provider-state relationship may implicate the government in religious experience. Under the current program, the criteria for provider eligibility are capacious, inviting both religious and nonreligious institutions, as well as relative care and homebased care. In general, the program tends to draw a wide variety of providers and in no way tends to favor religious institutions over any other type of provider. ${ }^{105}$ With respect to entanglement concerns, the current program gives little ground for worry. Because the standards for inclusion of providers focus primarily on health and safety of children, the government's ongoing monitoring includes, at most, an occasional inspection designed to ensure compliance with these concerns. ${ }^{106}$ Such inspections present little risk that government agents will try to reshape the religious content of these child care programs.

As in the case of the recipient-government relationship, however, one can imagine revisions to the government-provider relationship that raise legitimate constitutional concerns. First, as before, if relative and home-based care are eliminated from the mix of eligible providers, the percentage of religious institutions among the providers necessarily increases. As the proportion of religious institutions increases, the argument that government is steering recipients toward religious experience becomes correspondingly stronger. Second, without regard to the inclusion of relative and home-based

105 The original version of the Child Care and Development Block Grant scheme required states to offer payment rates at an amount equal to or greater than that charged by local providers at the 75 th percentile, but the 1996 welfare reform eliminated this requirement, and a number of states now set rates at a lower amount. Besharov \& Samari, supra note 84, at 200. Because average rates tend to be lower for home-based care and relative care than for day care centers, however, see id., lower payment skews the market away from child care in religious institutions rather than towards it.

106 Unlicensed providers are not subject to standards, and critics complain that enforcement of standards, especially those that pertain to quality of care, are not well-enforced. Besharov \& Samari, supra note 84 , at 208-09. 


\section{Vouchers and Religious Service Providers}

care, the amount paid per voucher recipient might nevertheless operate to steer recipients toward religious institutions. If the amount paid per voucher recipient is limited to that charged by the lowest-cost providers, and religious institutions dominate that class of providers, recipients will be more likely to choose such institutions. That tendency can be exacerbated by a rule that bars any provider that accepts vouchers from charging recipients more than the voucher amount. Under such conditions, higher cost providers would take a loss on any service extended to voucher recipients, thus discouraging these providers from participating in the program, and simultaneously increasing the proportion of religious institutions in the mix of providers.

Third, one can also imagine more frequent and intrusive monitoring of child care programs than that occasioned by health and safety inspections under the current regime. If the hypothetical child care program specifically intends the social, intellectual, and moral development of children, the monitoring of compliance with these objectives, coupled with state concern over impermissible steering, might well involve extensive interaction between government agents and child care providers with respect to the means used to advance these objectives. When the providers are religious institutions, such interactions run the constitutional danger of making the government a coauthor of the religious mission.

Our analysis of the relationship between the state and providers thus reinforces and extends our prior analysis of the relationship between the state and recipients. Recall that the overarching question for the constitutionality of voucher programs is whether the government may reasonably be held accountable for whatever religious experience voucher recipients may have in these programs. The government may steer recipients toward religion in a variety of ways, including compelling recipients to accept particular services, especially services already dominated by religious providers, and structuring policies for eligibility and payment of providers that intentionally or unintentionally privilege religious providers. Furthermore, by financing programs intended to transform recipients' lives in fundamental ways, and evaluating the methods used in such programs, the government may find itself enmeshed with providers in determining the place and effectiveness of religious experience in personal transformation.

\section{The Relationship Between Recipients and Providers}

Of the three legs of the voucher triangle, the relationship between recipients and providers has received the least explicit attention from courts and scholars. The fact that recipients and providers are private rather than 


\section{The Journal of Law and Politics}

state actors may explain this relative inattention. Ordinarily, constitutional limitations do not apply to private actors. In the context of privately-financed delivery of social or other services by religious institutions to individuals, the Religion Clauses play no part. ${ }^{107}$ Moreover, the fact of government financing alone does not transform private actors into agents of the state. ${ }^{108}$

If, after analysis of the other two legs of the voucher triangle, one concludes that the government is not constitutionally accountable for any religious experience in the program, examination of this third leg cannot change the result. For example, in the "Book Stamps" program, the absence of evidence that government is steering book buyers into religious experiences renders the relationship between voucher recipients and booksellers constitutionally irrelevant. Even if some booksellers pressure customers to buy religious books, the Establishment Clause is not offended; indeed, the Free Exercise Clause and other parts of the First Amendment protect the bookseller's freedom to encourage customers to buy, and customers' freedom to choose, books on any subject. This conclusion is amply supported by the Court's decision in Witters v. Washington Department of Services for the Blind, ${ }^{109}$ in which a unanimous Court held that the Establishment Clause did not bar the inclusion of an education at a Bible college in a broad program of tuition grants for disabled, post-secondary students. Once the Court concluded that the program facilitated private choice among a wide variety of educational options, and therefore did not steer recipients in the direction of religious training, the fact that a particular student elected to use the grant to train for a religious vocation was not attributable to the state. ${ }^{110}$

${ }^{107}$ In the absence of relevant government involvement, the Free Exercise Clause presumably forbids government intrusion into the relationship between religious provider and recipient. The only exception to this might arise out of coercive and criminal mistreatment of recipients.

108 See Blum v. Yaretsky, 457 U.S. 991 (1982) (holding that a private nursing home is not a state actor when it decides to transfer patients supported by Medicaid, a government-financed program, from one level of care to another); Rendell-Baker v. Kohn, 457 U.S. 830 (1982) (holding that a private school receiving over $90 \%$ of its funding from the state is not a state actor when it fires a teacher because of her speech activities). A thorough analysis of this question can be found in Memorandum from Randolph D. Moss, Assistant Attorney General, Office of Legal Counsel, U.S. Department of Justice, for William P. Marshall, Deputy Counsel to the President, Re: Application of the Coreligionists Exemption in Title VII of the Civil Rights Act of 1964, 42 U.S.C. $§ 2000 \mathrm{e}-1$, to Religious Organizations That Would Directly Receive Substance Abuse and Mental Health Services Administration Funds Pursuant to $\S 704$ of H.R. 4923, the "Community Renewal and New Markets Act of 2000" (on file with authors).

109474 U.S. 471 (1986).

${ }^{110} I d$. at 487. Once courts reject the Establishment Clause defense to including this type of training in the state program, constitutional requirements of equality in the treatment of communications raise serious questions about the exclusion of religious training. See, e.g., Rosenberger v. Rector of the Univ. of Virginia, 515 U.S. 819 (1995). 


\section{Vouchers and Religious Service Providers}

Our interest in the recipient-provider relationship changes dramatically, however, if analysis of the other two legs of the triangle suggests that the state might be responsible for the recipient's religious experience in the program. When the state forces or steers recipients into services provided by religious institutions, or uses these programs to facilitate personal transformation, or closely monitors the religious content of the programs, the particulars of the recipient-provider relationship take on constitutional significance. In such cases, the participant's religious experience might plausibly be imputed to the state. The constitutional concerns reflected in this attribution could be mitigated, however, if the state-financed service were to be decoupled from the religious experience, allowing recipients to partake fully of the voucherfinanced service while remaining free to decide whether or not to participate in the providers' religious activities.

This sort of decoupling - which the Constitution requires in non-voucher programs - is far easier to accomplish in some situations than in others. Consider once more our hypothetical child care program - not the real onein which the limited mix of providers and the state's substantive goals of child development may lead to a conclusion that the state is constitutionally responsible for recipients' religious experience in the program. If providers are able to show that the religious experience is both separate from the statefinanced service and optional for recipients, the link between religious experience and state action is weakened. Even if the government has robust goals of child development, most child care service, especially for very young children, does not present the opportunity for religious instruction. Thus, in our hypothetical child care program, a specific religious provider might offer recipients the option of excluding their children from religious training and activities. At the times in which the program teaches lessons about sacred texts and worship practices, for example, it could teach alternative and secular lessons to those whose parents have objected to religious training. ${ }^{111}$

Such an opt-out strategy for alleviating Establishment Clause concerns is not equally possible for every provider in every voucher program. In contrast to the child care hypothetical, in which religious teaching may plausibly be severed from the secular remainder of the service, some voucher programs offer services in which religious experience or transformation are inextricably bound up with the state's objectives. The best example of such a program can be found in treatment for substance abuse in a market where religious

111 We assume here that the achievement of robust goals of child formation do not depend upon religious transformation. If this assumption is erroneous, the state should be permanently foreclosed from pursuing such goals. 


\section{The Journal of Law and Politics}

providers dominate. So long as the government expects such programs to produce significant characterological change - and not merely physical abstinence - the programs operated by faith-based organizations might not be separable into religious and secular components in ways that would permit recipients to select only the nonreligious elements. Where such opt-outs are feasible, however, they become secular alternatives to religion-based social services, despite the setting in an ostensibly religious institution. ${ }^{112}$ Expanding secular alternatives in this way in turn widens the choices available to recipients, and thereby ameliorates the constitutional vice of programmatic steering into religious experience.

\section{Viewing the three voucher relationships in combination}

Thus far, we have examined separately each of the three legs of the voucher triangle. Our analysis, however, has already begun to indicate some degree of interaction among these legs. In this section, we will develop more fully the connections among the various aspects of the voucher problem, highlight features of primary importance, and suggest a methodology for approaching the question of how and where to draw the line between constitutional and unconstitutional arrangements.

Our analysis of the legs of the triangle revealed a number of considerations worthy of attention, including 1) legal and factual compulsion of recipients;2) transformative program goals; 3 ) the number of providers, and the mix of secular and sectarian among them; 4) the ways in which government policies and market characteristics affect that mix; 5) government monitoring of providers and provider-recipient relationships; and 6) separability of service into religious and nonreligious components. In all circumstances, the government must employ formally religion-neutral criteria in determining eligible providers, and must not intentionally skew the mix toward religious providers. These are the government's threshold obligations.

Beyond these, the full spectrum of problems with vouchers can best be examined through a typology of interactions among all of the relevant variables. The typology, set forth immediately below, is structured around our judgment that, for any given combination of compulsion and transformation, the constitutionality of a voucher program will turn on the particulars of the mix among providers, the government's role in shaping that

\footnotetext{
112 When opt-outs are permissive, they are properly analyzed as part of the provider-recipient relationship alone. When, however, the state requires providers to make opt-outs available, the requirement can also be analyzed as part of the state-provider relationship. For the important bearing of mandatory optouts on the Cleveland school voucher problem, see infra note 174 and accompanying text.
} 


\section{Vouchers and Religious Service Providers}

mix, the government's monitoring of providers, and the severability of religious experience from the provided service.

\section{a. Compulsion and Transformation.}

Any program that combines these two characteristics ${ }^{113}$ places government under the most strenuous obligations, driven by concerns of free exercise as well as those of nonestablishment. Such programs require the government to ensure that all recipients have a meaningful choice of a nonreligious provider. Even if the criteria by which providers are selected are scrupulously religionneutral, the requirement of a meaningful choice cannot be satisfied unless there are sufficient nonreligious providers, of quality reasonably equal to the religious providers, so that every participant can select freely either a nonreligious or religious program. The government should bear the burden of persuasion on the adequacy of the mix among providers, ${ }^{114}$ and recipients should be entitled to individualized and fair procedures for resolution of any disputes about the constitutional sufficiency of the choices provided. Principles of due process require individualized proceedings in such cases, because recipients are forced to choose between religious liberty, on the one hand, and some other aspect of liberty or property, on the other. ${ }^{115}$ Only by

113 The most obvious example of such a program is mandatory treatment, aiming at comprehensive personal change, for the problems of substance abuse. See, e.g., Freedom from Religion Found., Inc. v. McCallum, 179 F. Supp. 2d 950, 955-59 (W.D. Wis. 2002) (describing role of faith in wide variety of personal changes sought by faith-intensive program aimed at treating substance abuse).

114 The appropriate placement of the burden of persuasion is an open question within current Establishment Clause doctrine. Although the Supreme Court has never focused on this precise issue, its formulation of the effects test in Establishment Clause cases leaves ample room for the view that apparent government support for a sectarian religious program triggers an obligation on the government to show that it has not caused forbidden, religion-enhancing effects. Perhaps the clearest statement of the state's responsibility to minimize the religion-advancing consequences of its actions appears in Justice O'Connor's concurring opinion in Pinette v. Capitol Square Advisory Board. 515 U.S. 753, 777 (1995) (O'Connor, J., concurring). In that opinion, Justice O'Connor argues that the state has an "affirmative obligation" to dissociate itself, by disclaimer or otherwise, from the religious message generated by the privately sponsored cross, erected by the Ku Klux Klan, in the public forum on the grounds of the statehouse. Id. at 777.

115 See, e.g., Perry v. Sindermann, 408 U.S. 593 (1972). In Perry, the Supreme Court held that a faculty member holding a form of contractual tenure at a state college must be provided an administrative hearing in which to test his allegation that he had been dismissed on the impermissible ground that he had expressed unpopular political views. Without such an opportunity to be heard, the faculty member might be forced to choose between his freedom of political speech and his constitutionally protected property interest in his job.

By comparison to the problem in Perry, a person alleging that she is being forced to choose between religious freedom to accept or reject a sectarian, faith-infused social service, on the one hand, and incarceration or a fine, on the other, should be similarly entitled to be heard on her complaint that she is being compelled impermissibly to surrender her religious liberty. 


\section{The Journal of Law and Politics}

meeting these stringent obligations can government fulfill its constitutional duty not to force people into religious experience.

Legal compulsion to participate in some government "service" may be somewhat exceptional. In a far greater range of circumstances, the compulsion to use the service will be factual rather than legal; that is, the service facilitates escape from desperate circumstances, even though there is no penalty associated with refusing the service. In such cases, government obligations remain strenuous, although significantly less so than in the case of legal compulsion. When government uses vouchers to make available an essential good or service, it is constitutionally irresponsible for it to remain indifferent to the possibility that the voucher program may generate significant factual pressure on recipients to undergo religious experience. Such indifference is a matter of attitude, not result, and we believe the Establishment Clause here should be construed to enjoin the government attitudinally as well as behaviorally - that is, it must be sensitive to these sorts of pressures, and it must make an affirmative, good faith effort to ensure that recipients have a substantively meaningful choice between secular and sectarian providers.

We will say more about this in connection with the Cleveland school voucher case, but here a different example should suffice. Suppose that government makes available through vouchers a program of treatment for substance abuse for all low-income people, completely independent of the criminal law. Such treatment is a matter of powerful need if the lives of those addicted to drugs or alcohol are to be improved with respect to physical health, economic well-being, familial relations, or otherwise. If the providers of such treatment are overwhelmingly faith-based, the state should not remain passive or indifferent to a provider demography that will effectively steer potential clients to faith, and discourage the irreligious from getting help. There are many ways in which government might act on this affirmative obligation, including offering its own secular service and creating financial incentives for private, secular providers to enter the market. The context of service will inevitably generate its own opportunities and constraints, but government should not sit back passively if voucher provision alone does not generate sufficient alternatives.

Even if all other obligations are satisfied, the state's monitoring of programs with transformative purposes presents additional constitutional dangers. First, such monitoring may take the form of government officials evaluating and trying to shape the content of explicitly religious programs in light of the state's goals. So long as there is an adequate mix of providers, the government may include intensively religious providers in voucher programs, 


\section{Vouchers and Religious Service Providers}

but it may not rigorously oversee the religious content of such services. ${ }^{116}$ Second, as noted above, transformative programs will invite monitoring of recipient progress. Voucher programs that have such transformative purposes and involve faith-intensive providers can be designed to meet constitutional limits, but the degree and kind of interaction between state agents and provider personnel will always be constitutionally sensitive.

\section{b. Compulsion without Transformation.}

A program of this type is best exemplified by child care vouchers for welfare recipients, who are under a statutory duty to work and thus must find child care. ${ }^{117}$ The program demands that child care providers satisfy only basic standards of health and safety and does not require providers to engage in efforts at shaping the character or intellect of the children in their care. In contrast to the most demanding obligations imposed on the state in programs of type a., this case presents a situation in which the obligations on the state are somewhat more relaxed. The feature of compulsion remains present, and the state accordingly remains obliged not to force anyone to place her child in a program that teaches religion. Here, however, the opportunity for parents to remove their children from some portion of the provider's program, without diminishing the secular value of the service, distinguishes this case from type a., in which secular and religious portions of the service are not readily divisible.

In the type b. example given, government must ensure that all recipients have secular options for child care, whether by way of a secular provider oran alternative unavailable in type a. cases - by way of the right to remove their children from religiously intense aspects of the program of a religious provider. This does not include the right to be free from exposure to all religious aspects of the provider, such as religious images on the wall or prayers before meals - the religious provider has not been transformed into a public institution - but only the right to be free from formative religious education. ${ }^{118}$ Thus, the required mix of providers in type b. cases is not

\footnotetext{
116 The government may, of course, monitor the output from such programs to ensure their effectiveness, and it may also monitor nonreligious aspects of the program, such as compliance with health and safety codes.

117 The obligation in the TANF program is qualified by requirements that the care be "appropriate," with recipients bearing the burden of demonstrating the inappropriateness of any particular form of child care, and that no state currently has a policy of appropriateness that makes any reference to the religious character of the available providers. See supra note 95.

118 Recall that the Establishment Clause question, as distinguished from the Free Exercise question raised by child placements, is whether the state is steering recipients into religious formation. Mild and passive exposure to religious symbols or messages probably does not rise to the level of formative
} 


\section{The Journal of Law and Politics}

measured by the institutional characteristics of religious providers; instead, the mix must be measured by the details of available programs, including relevant rights and opportunities to opt out of religious training.

In type b. cases, the monitoring dangers take on a different dimension. If the market lacks an adequate mix of religious and nonreligious providers, some — but not necessarily all — providers must provide opt-outs to cure the defect. Pressure from state agents on religious institutions to provide such opt-outs, if such institutions would rather not, and aggressive attempts by the state to control the boundary between secular and religious portions of programs both raise entanglement dangers. Monitoring in this situation can be accomplished within the constraints of the Constitution, but it must be done sensitively. Much will turn on the adequacy of instructions to monitoring agents. ${ }^{119}$

In the child care program as presently designed and operated by the states, the mix of available providers typically offers to parents ample choice, including care by religious and nonreligious institutions, home-based facilities, and relatives. Even if home-based and relative care were to be eliminated, the combined possibilities of secular providers and opt-outs in religious providers may produce a constitutionally adequate mix. As is the case in type a., however, the compulsory feature of the program should lead to an obligation on the state to demonstrate affirmatively the adequacy of the nonreligious options, and to provide some sort of fair opportunity to be heard for recipients who complain of compulsion to enroll their children in religiously focused programs. Even for those recipients compelled in fact and not in law to rely on child care vouchers - a category that will include virtually all low-income voucher recipients who are not also cash recipients of government welfare programs - the government remains obliged to make a

experience. This, of course, is a tough line to draw, but our judgment is that formative religious experience would be intense and extensive, and might include repeated emphasis on sacred stories and texts, or active instruction in modes and meanings of worship. The Free Exercise Clause, by contrast, might be violated by a legally coercive placement that required children to participate, even passively, in prayer or be subject to any religious experience.

119 Similar problems attend non-voucher programs, in which the Constitution requires that all service providers rigorously separate secular from religious aspects of the service. Overzealous monitors will drive all hints of faith from the program, thereby discouraging participation of faith-based organizations and their well-meaning representatives. Weak or poorly trained monitors will fail to protect the constitutional interest in keeping the state within its secular bounds. Policing the boundary always requires sensitive and thoughtful arrangements, whether the context is government contracts with faith-based organizations to provide social services, or instruction in the public schools in the secular significance of religious texts or events. For discussion of the latter problem, see Kent Greenawalt, Teaching About Religion in the Public Schools, 18 J.L. \& POL. ?? (2002). A properly designed voucher program, with ample choice between secular and religious providers, solves this problem by eliminating the need to monitor the faith content of the service. 


\section{Vouchers and Religious Service Providers}

good faith effort to have policies that will encourage the participation of secular providers. Moreover, if any monitoring for religious content occurs in such programs, its focus will likely be on the adequacy of the pre-monitored mix and the state's administrative approach to enhancing that mix. Trying to attract new, secular providers will always be a constitutionally safer choice than attempting to alter the programs offered by religious providers.

\section{c. Transformation without Compulsion.}

Any program that involves therapy or counseling about issues basic to the quality of human existence - for example, sexuality and reproduction, ${ }^{120}$ or drug dependency, or management of anger - includes personal transformation as at least one element of the government's purpose in supporting the program. When recipients' enrollment in one of these transformative programs is legally compelled, the program comes under the analysis in type a. Even when recipients have no legal duty to undergo the counseling or therapeutic experience, their failure to obtain the service may leave them in financially, emotionally, or physically difficult circumstances. At least in some circumstances, a voucher program that promises to help recipients address these difficulties, but includes only faith-infused providers, inevitably steers recipients toward religious experience, and falls under our analysis of factual compulsion in type a. above.

When potentially transformative programs are helpful but nonessential, the government's obligations are weaker. Counseling on sexuality and reproduction might fit this category best; information of this character always has transforming potential, but it is likely to be more incremental in its effect than individualized treatment for problems like substance abuse or uncontrollable rage. Formal neutrality between religious and secular providers is of course always required, but the government's affirmative responsibilities to be proactive about the mix of providers and, beyond that, to warrant reasonably adequate secular alternatives for the transformative service

\footnotetext{
${ }^{120}$ In Bowen v. Kendrick, 487 U.S. 589 (1988), the Supreme Court upheld against facial Establishment Clause attack a federal statute which authorized grants to, among others, religious organizations to engage in counseling teenagers on issues of sexuality and reproduction. The Court assumed that grantees could not use the federal support to engage in explicitly religious instruction. Id. at 604-05. The inextricable intertwining of the subject matter of counseling with religious precepts, however, was among the dissenters' reasons for taking a different view of the program. Id. at 634-42 (Blackmun, J., dissenting).
} 


\section{The Journal of Law and Politics}

presumably are less stringent when the service does not bear heavily, predictably, and frequently on life outcomes. ${ }^{121}$

Compulsion or no compulsion, government monitoring of programs with transformative purposes raises serious constitutional problems. The state may include faith-intensive providers in transformative voucher programs, but may not evaluate or shape the religious content of such providers' services. Moreover, state monitoring of recipients' religious progress should always be off-limits. As in type a., the government's relevant concerns are limited to secular measures of provider effectiveness and basic conditions of the provider's site, such as health and safety.

\section{d. Neither Compulsion nor Transformation.}

Any voucher program that neither requires participation, nor has personal transformation as its intended outcome, falls into this category. Such programs would include those providing opportunities for low-income persons to pursue athletic or vocational interests, or children to attend summer camp, as well as our hypothetical "Book Stamps." 122 None of these programs is ordinarily compulsory in the legal or factual sense, and transformation, though always possible when fresh experiences are offered, is not a feature of the programs' design. As always, the government is required to use formally religion-neutral criteria for selecting eligible providers and setting voucher amounts. Beyond this requirement of formal neutrality, however, the government's obligations in type d. programs are quite modest. The lack of transformative purposes in the program, coupled with the absence of compulsion, means that the government ordinarily can have confidence that a voucher system will not steer recipients into religious experience.

As we explained with respect to type $b$. cases, nontransformative services typically can be disaggregated into religious and nonreligious components. Under these conditions, religious providers may offer recipients the option of excluding themselves from religious training and worship, and providers will

\footnotetext{
${ }^{121}$ Because no deprivation of liberty or property is at stake, in contrast to the compulsory programs in types a. and b., we do not believe that the government is obliged to provide a formal administrative hearing, with full due process rights, for recipients who feel they have not been offered an adequate secular provider. That said, the presence of administrative processes for those dissatisfied with the extent to which secular services are available would help to alleviate concerns that the government is steering recipients toward religious transformation. Moreover, the courts are open for those who wish to complain of the steering that may result from the alleged constitutional inadequacy of the mix. In such a case, however, the voucher recipients and not the state, bear the burden of persuasion on the question of steering.

122 The same could be said of Witters. Witters v. Wash. Dep't. of Servs. for the Blind, 474 U.S. 481 (1986). The program of tuition grants usable at vocational programs applied to a very broad class of potential service providers, and the government's objective was limited to creating vocational opportunities for the blind, as a way to make them more independent and self-sustaining.
} 


\section{Vouchers and Religious Service Providers}

typically have market incentives to make such offers. As is the case with type c. programs, challengers bear the burden of proving that government has failed to meet its constitutional obligation not to steer recipients into religious experience. And unlike voucher programs that fall in types a-c- that is, programs involving compulsion, transformation, or both — programs that fall within type d. should not trigger any affirmative obligations on the part of the government to make efforts to bring secular providers into the market.

Although entanglement problems are possible in type d. programs, they are less likely to appear in such cases than in the other three. The government's obligation is at its lowest, so pressure upon it to monitor content, or to push for opt-outs, will correspondingly be lowest as well.

\section{The voucher typology at work.}

The scheme we have offered is designed to advance practical reasoning about voucher programs that fall between the easy cases at either end of the spectrum. We want to emphasize that we are not trying to advance yet another contestant in the elusive struggle to find adequate judicial "tests" of constitutionality under the Establishment Clause. Indeed, we hope to influence decision-makers faced with initial questions of program design, as much as, or perhaps more than, we might persuade adjudicators to use our suggested criteria to measure the ultimate constitutional validity of voucher programs. For each type of program, the framework offers a standpoint from which to view the relevant constitutional factors.

More concretely, the framework suggests highly particular stepsreligious opt-outs, voucher pricing strategies, or government participation as a service provider, among others - that the state might take to insure that it is not steering recipients into religious experience. One might best characterize the approach as an attempt to identify potentially saving features of voucher programs upon which designers of such programs may rely. We recognize that the certainty and predictability that many communities will need in order to experiment with voucher programs depend upon advance knowledge and insight about such features.

We are sufficiently without scholarly humility, however, that we are willing to suggest that the framework we have prescribed may also function effectively in constitutional adjudication. Indeed, we are mindful that its incorporation into such adjudication would be the most efficient device for persuading policymakers that our analytic approach is useful to them. Accordingly, in the next and final part of the paper, we apply in detail the 


\section{The Journal of Law and Politics}

methodology developed in this section to the particular problem presented by Cleveland's school voucher program, now before the Supreme Court.

\section{SCHOOL VOUCHERS IN CLEVELAND}

The constitutionality of vouchers for elementary and secondary education presents a rich context in which to test our ideas. Frustrated by the poor performance of public schools in cities across the United States, many legislators and educational reform advocates have turned to the mantra of parental choice in the selection of their children's schools. This movement has been driven in part by a faith in markets; introducing competition among providers of educational services, advocates believe, will create market-based incentives for existing schools to improve. Further, parents will feel empowered in making decisions concerning placement of their children, and children will receive better educations. ${ }^{123}$ The movement has also been supported by those who see public schools as poorly-equipped (and largely unmotivated) to teach basic moral values, and who see private schools, including sectarian schools, as the only real possibility for addressing this deficiency. ${ }^{124}$ And, of late, the most powerful argument of all in favor of school vouchers - the argument that has liberals wringing their hands - is that vouchers offer the best source of hope and opportunity to poor children of color who are trapped in violent and uninspiring urban public schools. ${ }^{125}$

\footnotetext{
123 See, e.g., ChUBB \& MoE, supra note 6.

124 See, e.g., Joseph P. Viteritti, Choosing Equity: School Choice, the Constitution, AND CIVIL SOCIETY (1999).

125 See, e.g., JoHn E. COONS \& STEPHEN D. SUGARMAN, SCHOLARSHIPS FOR CHILDREN (1992); Neal Devins, Social Meaning and School Vouchers, 42 WM. \& MARY L. REV. 919 (2001) (arguing that the voucher debate is now about helping poor urban children instead of bailing out sectarian schools or empowering middle-class suburbanites, and that this altered social meaning will lead courts to uphold voucher arrangements); John Viteritti, Reaching for Equality: The Salience of School Choice, 14 J.L. \& POL. 469 (1998). The voucher campaign is but a part of a larger movement in favor of school choice for low-income families. In an important recent piece, James Ryan and Michael Heise argue that suburbanites, fearful of the effects of the campaign on suburban public schools and property values, have tended and will continue to oppose efforts designed to expand school choice programs that would include suburban schools as options for urban children. James E. Ryan \& Michael Heise, The Political Economy of School Choice, 111 YALE L.J. 2043 (2002). James Dwyer has advanced a new and creative argument for an expansive voucher program designed to his specifications, which would require participating schools to abandon religious education of the sort typically found in sectarian schools. Such a program might liberate children from what Dwyer sees as the stultifying effects of conservative and traditional religious ideologies. DWYER, supra note 17. However sound intellectually or pedagogically, Dwyer's view is not likely to attract any political support in the short run. His liberal allies reject vouchers as a threat to public schools, and supporters of voucher programs would reject both his limitations upon participating schools and his underlying philosophy, which de-emphasizes parental choice and asserts the right of children to a progressive education.
} 


\section{Vouchers and Religious Service Providers}

No state or city has enacted anything like a full-scale voucher program, one that includes all students and effectively permits them to rely on voucher financing to select freely among all accredited schools, whether public or private. In several jurisdictions, however, legislators have approved more limited programs, designed to liberate small numbers of economically disadvantaged students from schools that are failing. Such programs now exist in Milwaukee, Cleveland, and the State of Florida. ${ }^{126}$ Several years ago, the Wisconsin Supreme Court upheld the Milwaukee program against constitutional attack. ${ }^{127}$ The Florida program is limited to students in chronically underperforming public schools, and is currently financing the education of very few students. ${ }^{128}$ In Simmons-Harris v. Zelman, the federal district court in Cleveland enjoined the operation of Ohio's voucher program; ${ }^{129}$ the Sixth Circuit affirmed, ${ }^{130}$ and, as of this writing, the case is under advisement in the U.S. Supreme Court.

\section{A. The Facts in Cleveland}

The especially dire condition of Cleveland's public schools led a federal court, with jurisdiction arising from a longstanding desegregation case, to place Cleveland's school system under direct state control. ${ }^{131}$ In 1995, the

126 A number of New England states pay tuition to students from rural areas who must attend high school out of district. These programs routinely include private secular schools, but exclude private religious schools, which the states believe they may not include because of federal or state constitutional limits. These policies have been upheld in recent years in Strout v. Albanese, 178 F.3d 57 (1st Cir. 1999); Bagley v. Raymond School District, 728 A.2d 127 (Me. 1999); and Chittenden Town School District v. Vermont Department of Education, 738 A.2d 539 (Vt. 1999). An outcome in favor of the state in the Cleveland voucher case would cast doubt on the validity of this practice.

A few other states, including most notably Arizona, have enacted schemes that provide tax credits for contributions to private organizations that in turn provide scholarships at private sectarian and nonsectarian schools. See Kotterman v. Killian, 972 P.2d 606 (Ariz. 1999) (upholding tax credit scheme against state and federal constitutional attack). For a discussion of tax credit schemes of this character, see Adele Robinson, Risky Credit: Tuition Tax Credits and Issues of Accountability and Equity, 11 STAN. L. \& POL'Y REV. 253 (2000).

127 Jackson v. Benson, 578 N.W.2d 602 (Wis. 1998), cert. denied, 525 U.S. 997 (1998).

128 Ryan \& Heise, supra note 125, at 38 (reporting that only 52 students in Florida were receiving vouchers under the program as of 2000).

12972 F. Supp. 834 (N.D. Ohio 2000).

130234 F.3d 945 (6th Cir. 2000).

131 According to the Brief for the United States as Amici Curiae, "the Cleveland district met none of the 18 state standards used to evaluate minimum acceptable performance, and students in the district performed far worse than students in other Ohio public schools. A 1996 report, for example, found that only $9 \%$ of [Cleveland's] high school students pass all four sections of Ohio's ninth grade proficiency test." Brief of Amici Curiae United States at 4, Zelman v. Simmons-Harris, 2002 U.S. LEXIS 4885. Students continue to drop out of the Cleveland school system at high rates; many drop out without completing the ninth grade. See Zach Schiller \& David Focareta, Cleveland's Diploma Deficit, Policy Matters Ohio, at www.policymatterohio.org/diplomadeficit.pdf (July 2001). 


\section{The Journal of Law and Politics}

Ohio General Assembly responded to this transfer of control by enacting the Pilot Project Scholarship Program. This program offers parents of children in Cleveland public schools a choice between two different vouchers for education. The first voucher option involves scholarships for tuition at private schools in Cleveland, or at public schools in the surrounding suburban districts, if they elect to participate. As summarized by the Sixth Circuit:

The voucher program pays scholarships according to family income. The program requires participating private schools to cap tuition at $\$ 2500$ per student per year and pays $90 \%$ of whatever tuition the school actually charges for low-income families; for other families, the State pays $75 \%$ of the school's tuition up to a maximum of $\$ 1875 .{ }^{132}$

The program provides for a lottery system to distribute the vouchers to eligible schoolchildren, with preference given to low-income families. ${ }^{133}$ Students enter the program in grades K-3, but may remain in the program through the 8th grade. Any private school within the boundaries of the Cleveland public school district is eligible to participate in the voucher programs. Such schools need to meet Ohio's basic accreditation requirements, agree not to "discriminate on the basis of race, religion, or ethnic background," and must "not advocate or foster unlawful behavior or teach hatred of any person or group on the basis of race, ethnicity, national origin, or religion." 134

The second of the two voucher options applies to parents who choose to keep their children in public schools. This group can obtain vouchers for special tutoring. As with the vouchers for private school tuition, low-income parents who seek tutoring assistance for their children receive $90 \%$ of the

\footnotetext{
132 Simmons-Harris v. Zelman, 234 F.3d 945 (6th Cir. 2000). See Ohio Rev. Code AnN. $\S$ 3313.976(A)(8), 3313.978(A) (Anderson 2001). The statute defines "low-income" as income below $200 \%$ of the poverty line. $I d$. at $\S 3313.978(\mathrm{~A})$.

133 If there is more demand for scholarships than supply, scholarships are distributed by lottery. For grades K-3, the priority of admission is students enrolled the previous year; then, at the school's discretion, siblings of children already enrolled; then children from low-income families until their number reaches $20 \%$ of the total enrolled in the previous year in that grade. If there are more scholarship-holding applicants than available seats, admission is by lot. If these three groups do not take up all seats for scholarship students, admission is by lot from other, non-low-income applicants. OHIO REV. CODE ANN. § 3313.977(A)(1) (Anderson 2001). For grades 4-8, previously enrolled students must be admitted first, and then the school may admit at its discretion. Id. at § 3313.977(A)(2). See generally, School Vouchers: Publicly Funded Programs in Cleveland and Milwaukee, United States General Accounting Office Report 01-914 (August 2001), available at http://www.gao.gov/new.items/d01914.pdf.

134 OHIo Rev. CodE ANN. §§ 3313.976(A)(4) \& (6) (Anderson 2001).
} 


\section{Vouchers and Religious Service Providers}

state-established limit, currently set at $\$ 400$, while other families receive $75 \%$ of that limit. ${ }^{135}$ The law requires that the number of tutorial assistance grants available must be equal to the number of scholarships awarded in a given year. ${ }^{136}$

The voucher program commenced operation in the 1996-97 school year. In the first year, the program granted scholarships to 1,994 students, 77 percent of whom attended religious schools. By the 1999-2000 school year, the number of scholarships climbed to 3,761, with 97 percent attending religious schools. ${ }^{137}$ The rise in percentages of voucher students in religious schools between 1996 and 1999 can be attributed to Ohio's enactment of a community schools program in 1997 . Community schools-more commonly known as "charter schools" - receive state funds, but are independent of the local school board's control. Several of the largest non-religious private schools that participated in the first year of the Scholarship Program recreated themselves as community schools, which enabled them to receive larger perstudent amounts from the state (an average of $\$ 4,518$, compared to the maximum of $\$ 2,250$ for scholarship students). ${ }^{138}$ In the 1999-2000 school year, 1962 students attended ten community schools. ${ }^{139}$

In addition to these ten community schools and the private schools participating in the Scholarship Program, parents in Cleveland potentially have several other alternatives to their neighborhood public schools. One such option thus far has not materialized - the voucher program permits the scholarships to be used at participating public schools in the surrounding suburban school districts, but none of those districts has ever agreed to accept voucher students. ${ }^{140}$ One asserted explanation for this is that the

135 Id. at $\S \S 3313.978(\mathrm{~B}) \&(\mathrm{C})(3)$.

${ }^{136} \mathrm{Id}$. at $3313.978(\mathrm{~B})$.

137 For a breakdown of the sectarian character of the participating schools in 1999-2000, and a breakdown of the number of Scholarship students in schools of each religious sect, see infra note 172. The 2001-2002 scholarship number is 4,195, with roughly the same proportion attending religious schools as in 1999-2000. Amy Hanauer, Cleveland School Vouchers: Where the Students Go, Policy Matters Ohio, at http://www.policymattersohio.org/WhereStudentsGo.pdf(Jan. 2002). See also Ralph G. Neas, Five Years and Counting: A Closer Look at the Cleveland Voucher Program, People for the American Way, at http://www.pfaw.org/issues/education/reports/cleveland-9-21.pdf (Sept. 25, 2001).

138 Affidavit of Steven M. Puckett, Assistant Superintendent for Public Instruction, Ohio Dept. of Education, Joint Appendix at 161a-163a, Zelman v. Simmons-Harris, 2002 U.S. LEXIS 4885. The Hope Academies, which had been created in response to the Scholarship Program, shifted to the community schools program because the per pupil amount is so much higher. Affidavit of Jay P. Greene, $i d$. at 209a, Zelman v. Simmons-Harris, 533 U.S. 976 (2001) (No. 00-1751) ("The Hope schools, which have now been reestablished as community schools, educated nearly $15 \%$ of all scholarship students in past years.").

${ }^{139}$ Affidavit of Steven M. Puckett, $i d$. at 161a-162a.

140 Simmons-Harris, 234 F.3d at 949. 


\section{The Journal of Law and Politics}

reimbursement amount for these public schools remains significantly below their present expenditures per student, thus effectively requiring them to subsidize Cleveland students attending their schools. ${ }^{141}$ Magnet schoolsspecialized schools within the Cleveland public school system - provide a more realistic choice for parents; in 1999-2000, over 13,000 students were enrolled in 23 Cleveland magnet schools. ${ }^{142}$

Immediately after the Scholarship Program was enacted, it faced legal challenges from teachers' organizations and religious liberty groups. In 1999, the Ohio Supreme Court found that the program's original enactment had violated a procedural requirement in Ohio's Constitution, but the program was quickly reenacted. ${ }^{143}$ During the state court challenges, the original Scholarship Program continued to operate. In August of 1999, the challengers filed suit in federal district court against the reenacted program. ${ }^{144}$ In December of 1999, the District Court granted summary judgment to the challengers of the voucher programs, but stayed a permanent injunction of the program pending review in the Sixth Circuit. In December of 2000, the Sixth Circuit affirmed the district court's decision; it too continued the stay, pending petitions for certiorari. The Supreme Court granted certiorari in September of 2001, and heard argument in the case in February of 2002. During these court challenges, the Scholarship Program has continued its operation, though the legal uncertainty surrounding the program may have discouraged new private schools from entering the market.

\footnotetext{
${ }^{141}$ Respondents' Brief at 29-31, \& n.11, Zelman v. Simmons-Harris, 2002 U.S. LEXIS 4885. This assertion, however, conflates the difference between average cost per pupil and the marginal cost of educating one additional pupil. The latter may be considerably less than $\$ 2500$ in the suburban schools. Moreover, other, less benign, reasons might help explain suburban reluctance to participate: perhaps the suburbs want to wall themselves off from the City's problems, or prefer not to have poor minority children in their schools. See generally Ryan \& Heise, supra note 125. In addition, clever lawyers from teachers' unions might have recognized that suburban nonparticipation weakens the mix of schools, and that this nonparticipation may be a factor in the constitutional demise of voucher programs, which these unions oppose on the ground that they will tend to undermine financial support for public schools.

142 A study of the Cleveland system by Jay Greene claims that there are more than 16,000 students enrolled in magnet schools in 1999-2000. See Affidavit of Jay P. Greene, supra note 138, at 217a. In its brief in the Supreme Court, the State of Ohio claims only 13,000 students are enrolled in Cleveland's magnet schools. Petitioner State of Ohio's Brief at 8, Zelman v. Simmons-Harris, 2002 U.S. LEXIS 4885.

143 Simmons-Harris v. Goff, 711 N.E.2d 203 (Ohio 1999).

144 The district court issued a preliminary injunction, ordering the Scholarship Program halted for the next school year. Coming so close to the start of the school year, the preliminary injunction created significant inequities for families whose children had been attending private schools in prior years on Ohio Scholarships; ultimately, the court modified its order, allowing voucher students enrolled in the previous year to continue, but barring new students from entering the program. The U.S. Supreme Court subsequently lifted the district court's injunction entirely, allowing new students to enter the program in the 1999-2000 school year.
} 


\section{Vouchers and Religious Service Providers}

\section{B. The Conflict in the Relevant Decisional Law, and the Sixth Circuit's Approach}

In deciding the issues presented in the Ohio voucher case, the Sixth Circuit panel faced the quandary that lawyers and judges have been confronting for years - the deep contradictions embedded in the law of the Establishment Clause. ${ }^{145}$ On one hand, reflecting the institutional concerns of the Establishment Clause, Supreme Court decisions have for many years emphasized the difference between government aid that flows directly to religious institutions, ${ }^{146}$ and aid that incidentally benefits such institutions but flows through the hands of private individuals. ${ }^{147}$ This distinction, which lies at the heart of the fight between voucher proponents and opponents, originates in Everson v. Board of Education of Ewing Township, ${ }^{148}$ the germinal Establishment Clause decision in the Supreme Court. Everson involved reimbursement to parents of children for the costs of public transportation to and from high schools, public and Catholic, all of which were located outside of the Township. Although recognizing that such aid reduced the overall costs of attending sectarian schools, and declaring that such aid went to the verge of constitutional power, the Court in Everson treated such aid as constitutionally equivalent to the provision of police and fire protection to sectarian schools. Denying such aid to parents of children in Catholic schools, the Court held, would be an act of forbidden hostility to sectarian education.

The idea that reimbursement for bus tokens represented the constitutional verge vanished in Board of Education of Central School District No. 1 v. Allen, ${ }^{149}$ decided in 1968. Allen upheld New York's plan for defraying the costs of sectarian education by paying for schoolbooks for children in private schools. The New York plan involved the loan to families of schoolchildren of books used in fact, or approved for use, in the public schools. The plan built on Everson's approval of the reimbursement to families for transportation costs; the limitation on which books could be purchased by the State, and loaned to families, was designed to avoid the problem of state acquisition of books with a sectarian religious flavor. The program made

\footnotetext{
145 For an excellent social and political account of the confusing and contradictory impulses in this body of law, see John C. Jeffries, Jr. \& James E. Ryan, A Political History of the Establishment Clause, 100 MICH. L. REV. 279 (2002).

146 See, e.g., Mitchell v. Helms, 530 U.S. 793 (2000); Agostini v. Felton, 521 U.S. 203 (1997); Lemon v. Kurtzman, 403 U.S. 602 (1971).

147 Zobrest v. Catalina Foothills Sch. Dist., 509 U.S. 1 (1993); Witters v. Wash. Dep't. of Servs. for the Blind, 474 U.S. 481 (1986); Mueller v. Allen, 463 U.S. 388 (1983); Bd. of Educ. v. Allen, 392 U.S. 236 (1968); Everson v. Bd. of Educ., 330 U.S. 1 (1947).

148330 U.S. 1 (1947).

149392 U.S. 236 (1968).
} 


\section{The Journal of Law and Politics}

sectarian education cheaper for families, because, in its absence, they would have had to buy schoolbooks rather than, as was the case in the public schools, have them provided without charge for use during the school year. But Allen represented a large step beyond Everson, because the aid approved in Allen operated to subsidize the educational program rather than to guarantee the safety of students as they traveled to and from such programs.

The constitutional themes represented by Everson and Allen proliferated in the 1980's and 1990's. Mueller v. Allen ${ }^{150}$ upheld a state income tax deduction for families paying elementary and secondary school tuitions, despite the fact that the benefit of the tuition deduction went overwhelmingly to families in sectarian schools. Witters v. Washington Department of Services for the Blind, ${ }^{151}$ noted earlier, ruled unanimously that the state could make a tuition grant to a blind student who wanted to attend a Bible college to train for a career as a pastor; all of the Justices in Witters appeared significantly influenced by the wide mix of choices, almost all nonreligious in content, available to recipients of tuition grants for higher education. And Zobrest $v$. Catalina Foothills School District ${ }^{152}$ held that the Establishment Clause did not justify withholding a hearing interpreter, provided at public expense under the Individuals with Disabilities Education Act, from a hearing impaired young man who attended a highly sectarian school.

One might think that the line of decisions running from Everson to Zobrest would erase constitutional doubts about the validity of the Ohio voucher plan. Like all of the schemes for aid upheld in those decisions, the Cleveland plan funnels aid to families, as a tuition subsidy, rather than transfer resources, uninfluenced by individual family choice, to sectarian schools themselves. Pushing the other way, however, is a series of decisions from Separationism's heyday in the early 1970's. These cases, beginning with Lemon $v$. Kurtzman ${ }^{153}$ in 1971, reflect judicial hostility to any program that renders substantial aid to a set of private elementary and secondary schools that is dominated by sectarian schools in general, and Catholic schools in particular. Although preceded by Everson and closely preceded by Allen, these decisions invalidated various programs, enacted by northeastern states and designed to shore up the Catholic school system. Such rescue operations served several purposes, chief among them the protection of the public schools from the large numbers of children that would suddenly be forced into

\footnotetext{
150463 U.S. 388 (1983).

151474 U.S. 481 (1986)

152509 U.S. 1 (1993).

153403 U.S. 602 (1971).
} 


\section{Vouchers and Religious Service Providers}

the public system if the Catholic schools were to close. Most of the decisions in this line involved non-voucher arrangements - that is, they involved direct transfers to sectarian schools, not dependent on the numbers of families electing to have their children attend such schools. ${ }^{154}$ As such, they stand for the unexceptional proposition that the state may not directly support the religious instruction the Court believed to be pervasive in the benefited schools. ${ }^{155}$

In a pair of cases decided in June of 1973, however, the Supreme Court extended the holdings of these "no-aid" decisions to programs involving tuition reimbursement to parents of children in such schools. In Committee for Public Education and Religious Liberty v. Nyquist, ${ }^{156}$ the Court invalidated a scheme that provided either a lump sum tuition grant or a tax credit to low- and middle-income parents with children in private schools, ${ }^{157}$ most of which were sectarian and Catholic. The grants and credits were keyed to family income, and were capped at $50 \%$ of the tuition actually paid per child. There had been no factual inquiry in the lower courts into the effect of the tuition grants on the financial position of sectarian schools; rather, the Supreme Court assumed, without proof, that such programs inevitably resulted in aiding such schools. ${ }^{158}$ Of course, such programs might indeed have aided sectarian schools, either by forestalling the flight of poor parents to free public schools, or by adding sufficiently to the resources of parents so

154 Wolman v. Walter, 433 U.S. 229 (1977), overruled by Mitchell v. Helms, 530 U.S. 793 (2000); Meek v. Pittenger, 421 U.S. 349 (1975), overruled by Mitchell v. Helms, 520 U.S. 793 (2000); Levitt v. Comm. for Pub. Educ., 413 U.S. 472 (1973); Lemon v. Kurtzman, 403 U.S. 602 (1971).

155 Mitchell v. Helms, 530 U.S. 793 (2000), overruled Meek and Wolman, both of which involved the provision of pedagogical equipment or materials that were restricted in use to secular purposes.

156413 U.S. 756 (1973). A companion case, Sloan v. Lemon, 413 U.S. 825 (1973), held that the Equal Protection Clause did not compel Pennsylvania to extend similar tuition grants to parents of children in sectarian schools once the state made them available to parents of children in private, nonsectarian schools.

157 The grants in Sloan were made without regard to parental income. 413 U.S. at 831. The grants in Nyquist were limited to one-half of tuition, capped at $50 \%$ of tuition actually paid, and went only to lowincome families. 413 U.S. at 756. Families with slightly higher income received "tax credits," which bore no relation to taxable income and which declined to zero as income increased. Id. at 757 .

158 The entirety of the Court's analysis of the effects of the tuition grants is as follows:

By reimbursing parents for a portion of their tuition bill, the State seeks to relieve their financial burden sufficiently to assure that they continue to have the option to send their children to religion-oriented schools. And while the other purposes of the aid - to perpetuate a pluralistic educational environment and to protect the fiscal integrity of overburdened public schools - are certainly unexceptionable, the effect of the aid is unmistakably to provide desired financial support for nonpublic, sectarian institutions.

413 U.S. at 782-83 (footnote omitted). The Court in Nyquist also noted the high likelihood that political disputes over the future of the New York program would occur along sectarian lines and suggested that this sort of political divisiveness raised separate Establishment Clause concerns. Id. at 795-98. 


\section{The Journal of Law and Politics}

that they could bear tuition increases at sectarian schools. But the district court had decided the case at the stage of summary judgment, and neither of these propositions had been proven, or even subjected to any systematic economic analysis. ${ }^{159}$

Because Nyquist invalidated a program that transferred assistance to parents, not to religious institutions, it stands in sharp conflict with a number of decisions rendered before and since, and there is at least reason to doubt its continued force. Nevertheless, a majority of the Sixth Circuit panel in Zelman v. Simmons-Harris made Nyquist the centerpiece of its analysis and ruled the Scholarship Program unconstitutional. The Sixth Circuit emphasized certain key features of the Program: 1) unlike Allen and Zobrest, which upheld arrangements driven by beneficiary choice, and unlike the recent decisions upholding non-voucher arrangements, ${ }^{160}$ the Ohio Program involved the transfer of unrestricted funds, not goods and services, through beneficiary families to sectarian schools; ${ }^{161}$ 2) unlike Witters, which concerned the transfer of unrestricted funds to a Bible college's religion program, and unlike the tax deduction scheme in Mueller, the Ohio Program did not include public schools as entities in which recipients could use scholarships; ${ }^{162} 3$ ) in the Ohio Program, quite unlike the schemes upheld in Mueller and Witters, over $80 \%$ of participating schools are sectarian, and over $90 \%$ of participating students attend those schools; ${ }^{163}$ and 4) the Ohio Program, unlike Mueller and Witters, effectively set tuition rates for participating schools, and did so at a level that induced low-cost sectarian schools into the Program while effectively excluding higher cost secular schools. ${ }^{164}$ In combination, the Sixth Circuit ruled, these features signified that religious indoctrination in participating sectarian schools in Cleveland was properly attributable to the State. ${ }^{165}$

It is not difficult to see why judges on the lower courts are uncertain about how to analyze the constitutionality of plans like Ohio's. The relevant decisional law contains anomalies and internal contradictions sufficient to

159 The Court was in any event asking the wrong question. The correct inquiry is focused on the state's complicity in religious education and the significance of the tuition grants to that complicity.

${ }^{160}$ Mitchell v. Helms, 530 U.S. 793 (2000); Agostini v. Felton, 521 U.S. 203 (1997).

161 Simmons-Harris, 234 F.3d at 959.

162 Id. at 960 .

163 Id. at 959 .

${ }^{164} \mathrm{Id}$.

165 The existence of community schools and magnet schools, in the Sixth Circuit's view, was constitutionally irrelevant. $I d$. at 958 . Judge Ryan's dissent emphasizes every respect in which Cleveland parents have "choices," 234 F.3d at 963-974, but he does not probe the constraints on choice, and his opinion seems as fully result-oriented in affirming the meaningful quality of the choice as does the panel majority's opinion in denying it. 


\section{Vouchers and Religious Service Providers}

permit every prior decision to be distinguished on its facts. Without an overarching theory to explain why courts should adhere to the Nyquist approach over that represented by the other decisions upholding aid to individuals and families, it is impossible to say which line of decisions should control. Moreover, cases like Cleveland involve the sympathetic factor of saving children from a set of disastrously substandard public schools. Other features of the Cleveland story-a strong tilt toward sectarian schools in the mix of providers, the failure of suburban public schools to participate despite a statutory invitation to do so, and the uncertain role of community and magnet schools in the choices faced by Cleveland parents - all contribute to the sense that there must be a more systematic way to analyze the problem than blind adherence to Nyquist or Witters as a result of a precommitment to a Religionist, Secularist, Separationist, or Neutralist philosophy.

\section{The Cleveland voucher story seen through our framework}

The Ohio Scholarship program presents subtle and complex issues at every turn. We begin with the question of compulsory participation. The voucher program includes grades kindergarten through eight; virtually all children in this grade range are subject to Ohio's compulsory attendance laws, which compel all guardians of children under the age of 18 to ensure that their minor wards receive some version of acceptable education. ${ }^{166}$ Students must attend an accredited school or some approved alternative.

Viewed at the level of legal compulsion only, the mix of choices available in Cleveland is vast, and the compulsion to attend religious school is virtually nil. In addition to the religious schools participating in the Scholarship Program, which paid for almost 4000 seats in private schools in the year on which the litigation is focused, the options presented to parents include the Cleveland public schools, in which a seat is guaranteed to every child; magnet schools, which as of 1999-2000, include at least 13,000 seats; charter schools, known in Ohio as "community schools," which as of 1999-2000 include almost 2000 seats; and home schooling, among other less conventional options. ${ }^{167}$ It is impossible to describe this situation as one in which parents are legally compelled to enroll their children in religious schools.

As we have analyzed compulsion above, however, it is not limited to circumstances in which the recipient's unwillingness to accept the service

\footnotetext{
166 OHIO REVISED CODE ANN. §§ 3321.01-.03 (Anderson 2001).

167 These might include private schools outside of the district, health institutions in which severely disabled children might be educated, and full-time private tutors. None of these options is likely to have much effect on Cleveland parents with a thirst for their children to learn and few resources to satisfy it.
} 


\section{The Journal of Law and Politics}

results in legal penalties. Physical needs or normal human aspirations can make a service necessary, or at least highly desirable. Because legislators, judges, and parents recognized that the Cleveland public school system failed to deliver a minimally adequate education, parents with children in Cleveland public schools would not reasonably "choose" the unlimited seats available in their neighborhood public schools. ${ }^{168}$ Even if the parents were not legally compelled to send their children to religious schools, the disastrous condition of the Cleveland public schools made it practically necessary for parents to look elsewhere to meet their legal obligation and parental responsibility to educate their children. Thus, parents could reasonably say that they were compelled by a combination of law and fact to choose among 1) private schools participating in the Scholarship Program, 2) community schools, and 3) magnet schools operated by the Cleveland Public School System. The combination of legal compulsion to educate their children, and practical compulsion to avoid substandard schools, means that parents are not entirely free to accept or decline the offered exits from the neighborhood schools. 169

As suggested by one of the questions at oral argument in Zelman, ${ }^{170}$ the price incurred by a parent for accepting an Ohio Scholarship may be forced exposure of her child to religious indoctrination. It is true, as the State argued, that the record disclosed no instances of Scholarship parents who desired a secular private school option and couldn't get one. If, however, the best voucher schools are sectarian, parents who wanted the best education for their children may well have accepted the tradeoff between educational quality and unwanted — or minimally tolerable - religious indoctrination. Here, as in the case of prayer at public school commencement or sporting events, ${ }^{171}$ the state may not impose religious experience as the price of enjoyment of state-created opportunities.

168 But see Richard T. Welcher, Note, If A Public School is Labeled "Failing," Could More Really Be Less?, 77 NOTRE DAME L. REV. 293 (2001) (arguing that schools that are "failing," but have not entirely failed or closed, should be considered as part of the mix available for "choice" by parents).

169 This observation leads to another, rather striking one - when public schools are good, and vouchers seem less necessary, the constitutionality of voucher programs appears to be on much safer ground. When public schools are failing, the policy case for vouchers gets stronger, but the arguments needed to defend vouchers against constitutional attack become weaker.

170 Transcript of oral argument at 24-25, Zelman v. Simmons-Harris, 2002 U.S. LEXIS 4885. Although the transcript does not specify, our recollection from having attended the oral argument is that Justice Breyer asked this question.

${ }^{171}$ Santa Fe Indep. Sch. Dist v. Doe, 530 U.S. 290 (2000) (holding that public school may not authorize students to pray over the PA system at high school football game); Lee v. Weisman, 505 U.S. 577 (1992) (holding that public school may not include clergy-delivered prayer in middle or high school commencement). 


\section{Vouchers and Religious Service Providers}

Next, we turn to the issue of transformation, and more particularly, the relationship between the government's intended goals and any personal transformation engendered through the voucher experience. On the one hand, the government's primary aim in the school voucher program is to enable children to achieve at least minimum academic proficiency. This goal, taken alone, does not depend on the kind of personal transformation which, if religious, the state would be constitutionally forbidden to promote. On the other hand, the state's goals in the educational process extend beyond minimum academic competence; they include the values of good citizenship, honesty, and respect for others. Even if these goals do not reflect thick conceptions of the human good, children are subjected to this formation for 30-35 hours a week, many weeks of the year, and many of their formative years. This repeated exposure of highly impressionable young people to influences upon their character is likely to shape their moral identities for years to come. Personal growth and development may not be the state's primary goals, but they certainly count among the state's desired outcomes of elementary and secondary education.

Under these circumstances of mixed legal and factual compulsion, transformation over time, and a very high percentage of religious schools in the available mix for scholarship students, ${ }^{172}$ what must the state do to avoid the conclusion that the Scholarship Program is steering students into religious training? To answer this question, we return to the typology outlined above. The Cleveland voucher program displays qualities of compulsion and transformation rather removed from those found in our mandatory drug treatment program. Indeed, we readily concede that the amalgam of legal compulsion and personal transformation to this degree is not enough to trigger requirements of due process with respect to the placement of each child. Nevertheless, the combination should be sufficient to shift to the government the burden of showing that voucher recipients have sufficient nonreligious educational choices, reasonably equal in quality to the religious choices available, to preclude an inference that government is responsible for steering children into the religious training actually received by Program-financed

\footnotetext{
172 The Joint Appendix in Zelman includes information about the sectarian affiliation, if any, of the private schools participating in the Scholarship Program in the year 1999-2000. Joint Appendix at 281a286a, Zelman v. Simmons-Harris, 2002 U.S. LEXIS 4885. The total number of schools is 56, including 35 Catholic schools (educating a total number of 2962 Scholarship students), 2 "Christian" schools (260 Scholarship students), 1 Baptist school (44 Scholarship students), 6 Lutheran schools (219 Scholarship students), 1 Adventist school (80 Scholarship students), 1 Islamic school (67 Scholarship students), and 10 nonsectarian schools (129 Scholarship students). Sectarian schools represent 46 of the 56 participating schools and educate $97 \%$ of the Scholarship students. Catholic schools alone represent $63 \%$ of the participating schools and educate $79 \%$ of the Scholarship students.
} 


\section{The Journal of Law and Politics}

students. ${ }^{173}$ At the very least, the state must demonstrate that it has made a substantial and good faith effort to minimize its complicity in such steering.

In analyzing the state's obligation, we want to emphasize that the state's good faith efforts to meet that obligation may be more important than its short-run success in generating secular choices. In a context like that of schools, in which the pre-existing class of providers is likely to be dominated by sectarian entities, it will be extremely difficult for the state in the short run to guarantee secular options of sufficient quantity and quality to ensure that its policies do not have some steering effect. If attendance at a private school were legally compulsory, the paucity of secular options might well be fatal. In a setting of mixed legal and factual compulsion, and gradual transformation over time, the state's performance - at least initially — should be measured more by its effort than by its results. An effort-based measure would provide both opportunity and predictability for communities wishing to experiment with voucher programs, in ways that a result-driven measure would not. Among other things, an effort-based (rather than result-based) standard of constitutionality would eliminate the possibility that a voucher program could be constitutional one year and unconstitutional the next, depending upon the changing mix of providers in the market. If the state's efforts remain the same year-to-year in a program of this character, the constitutional outcome should be similarly constant.

Has the State of Ohio made a good faith effort to minimize the religious steering associated with the Scholarship program? We note three steps that the State failed to take, and which might have significantly affected the extent of religious experience caused by the program's design. First, and to our minds most tellingly, the State did not require participating schools to offer voucher-financed children the opportunity to opt-out of religious education. ${ }^{174}$ Such an opt-out would extend to attendance at worship services, and to classes devoted entirely to the subject of religion. Of course, voucher students who take advantage of such an opt-out would still be exposed to whatever religious content remained in academic classes; to permit students to opt out of religious content at that level would effectively require entirely

\footnotetext{
173 It is important to recall that Establishment Clause violations are "collective," not individual, and cannot be waived. See Esbeck, supra note 48. Like subject matter jurisdiction in federal courts, government authority over religious experience cannot be conferred by the parties. So the absence of objection from Cleveland families whose children are participating in the Scholarship Program does not moot the objection to the religious steering caused by the program.

174 The Milwaukee voucher plan does require participating sectarian schools to offer such an opt-out to voucher-financed students. Jackson v. Benson, 578 N.W.2d 602, 609 (Wis. 1998). The Florida plan also has an opt-out provision, but it is narrower than Milwaukee's. See Florida Stat. § 229.0537 (4)(j) (voucher students may not be compelled "to profess a specific ideological belief, to pray, or to worship").
} 


\section{Vouchers and Religious Service Providers}

separate classes for the voucher students, or the purging of religious content in academic classes for the entire student body. An opt-out of the sort we describe does not eliminate entirely the religious content from the curriculum of sectarian schools, but it does substantially reduce its volume and intensity. ${ }^{175}$ In Cleveland, however, participating schools - though they may not discriminate on the basis of religion in accepting voucher students - are under no such command from the State to permit opt-outs from religion class or worship services.

It may well be, of course, that the State's transformative goals are better served if voucher students are immersed in faith, but the Establishment Clause precludes the State's intentional reliance on religious means to serve these ends. Moreover, the transformative goals of education do not depend, even in a weak sense, on religious immersion; they depend, instead, on longstanding exposure to lessons in, and models of, good character. A more constitutionally reasonable argument against an opt-out requirement is that the State's academic and transformative goals may be better served if voucher students are not put in the spotlight on account of their religious differences. If meaningful parental choice rather than State choice is the key to the voucher problem, however, the hard question of whether to put a child in a religious school while keeping the child out of the school's religious program should be left to parents, not to the state or providers. An opt-out requirement might drive some providers away, but it would simultaneously help the State in satisfying the affirmative obligation that we think it should have to meet. ${ }^{176}$

In a second, conceptually important way, the state failed to take yet another step that would have evidenced its good faith and might have appreciably altered the mix of schools. The State of Ohio did not mandate the participation of suburban public schools, ${ }^{177}$ at least to the extent that such

\footnotetext{
175 Opt-outs will also reduce the damage that vouchers may do to religious minorities, tempted by the educational benefits offered by voucher programs but at risk of religious discrimination and faith dilution in schools of faiths not their own. For an argument about vouchers that derives in part from concern for these values of religious equality, see Alan Brownstein, Evaluating School Voucher Programs Through a Liberty, Equality, and Free Speech Matrix, 31 ConN. L. ReV. 871 (1999).

${ }^{176}$ No party in Zelman made any mention of religious opt-outs for scholarship students. The state of course did not want to call attention to the possibility, because it would only put its program in a poorer light. The anti-voucher forces might have raised it, but they were committed to defeating vouchers for private schools under any and all circumstances, and therefore had no incentive to suggest a way in which the constitutionality of school vouchers might be saved. The State of Wisconsin did file an amicus brief in which opt-outs were mentioned, see Brief Amicus Curiae for the State of Wisconsin at 10, Zelman v. Simmons-Harris, 2002 U.S. LEXIS 4885, but there was no mention of them at oral argument.

${ }^{177}$ The State might also have invited suburban private schools to participate, but it is not clear whether that would have changed the mix in a nonreligious direction, especially if tuition caps were kept low.
} 


\section{The Journal of Law and Politics}

schools had available seats. Instead, it permitted but did not require such participation. Of course, such a mandate would have required considerable political will, partly because of suburban resistance to helping in the solution to the City's problems, ${ }^{178}$ and partly because the unions representing public school teachers, suburban and otherwise, are politically influential and deeply hostile to voucher programs. ${ }^{179}$ The absence of political will, however, hardly constitutes a good defense to a claim that the State has failed to meet its constitutional obligations to make an effort to ensure sufficient nonreligious choices in a voucher program. The State had taken over Cleveland's schools because of their rotten condition; stopping short of mandating participation by high-quality suburban school systems in the amelioration of Cleveland's problems is one sign of insufficient effort in the discharge of the State's constitutional duties, triggered by its decision to make vouchers available.

In yet a third, perhaps more tenuous way, the State has made a suboptimal effort at expanding the mix of voucher schools. The State might have set the tuition amount in the Scholarship Program at a level high enough to attract a wider range of secular private schools. As we argued in Part II.B., above, the pricing of vouchers is an aspect of the state-provider relationship that may affect the range of recipient choice. In concluding that the Scholarship Program was nonneutral, the Sixth Circuit relied explicitly on the fact that tuition had been set at $\$ 2500$. The result of this, the Court reasoned, is to "discourage[] the participation by schools not funded by religious institutions ... [because it is only the] religious schools [that] often have lower overhead costs, supplemental income from private donations, and consequently lower tuition needs." 180 Thus, the Sixth Circuit concluded that the voucher amount operated as an impermissible gerrymander, disproportionately excluding secular schools that were unwilling or unable to educate children for $\$ 2500$ per year. ${ }^{181}$

\footnotetext{
178 This sort of resistance seems all too typical. Ryan \& Heise, supra note 125.

179 See Caitlin Scott, Bill Would Nearly Double the Amount of Tuition Vouchers. Goal is to Increase Non-religious Schools in the Program, at http://www.catalyst-cleveland.org/12-01/extra41201.htm (reporting an initiative by Republican state legislators to increase voucher amounts and attract new schools into the program, and noting that "the Ohio Parent Teacher Association, the Ohio Federation of Teachers, and the Ohio School Board Association, among other major school organizations, [are] opposed to vouchers on principle.").

180234 F.3d at 959 (citing Minow, supra note 100).

${ }^{181}$ By sharp contrast, the Milwaukee program upheld in Jackson paid "the lesser of the [Milwaukee Public School] per student state aid ... or the private school's 'operating and debt service cost per pupil that is related to educational programming' as determined by the State." 578 N.W.2d at 609 (citing WIS. STAT. $\S \S 121.08$ and $4006 \mathrm{~m}$ ). Moreover, the Florida Scholarship Program finances each voucher at a level akin to that used in Milwaukee. For this and other information on the Florida program and other voucher arrangements, both public and private, see http://www.schoolchoiceinfo.org. When the voucher amount is
} 


\section{Vouchers and Religious Service Providers}

This line of argument dovetails to some extent with our own, but we think there is considerably more to be said. On the one hand, it may be that higher tuition payments for Scholarship students will induce more secular schools, as well as more religious schools, into the market, and it may be that the new entrants will be skewed in the direction of secular schools. Without more facts about the existing and potential market, however, one can only speculate about these results. For any given increase in the tuition amount, existing schools may be drawn into the Program, or new schools may come into being, but whether these entrants will materialize depends on a complex mix of economic and other factors that might drive schools one way or another. In particular, the likelihood that new providers will materialize will always be much lower with respect to schools than some other kinds of enterprises, like child care, in which entry is much less dependent on economic and reputational capital. In addition, the fact that the Program was limited to 3700 Scholarships offered little promise to a new school hoping to sustain itself on Scholarship payments; with voucher amounts and the grand total of vouchers that low, no school could effectively sustain itself on Scholarship students.

Perhaps the best defense for the amount set by Ohio is that the state inevitably must allocate a total budget amount to these vouchers, and each increase in the value of the Scholarship will presumably produce a decrease in the total number of students helped. This last observation cannot justify intentional gerrymandering of the amount so as to favor religious schools, but it suggests caution about attributing bad faith to the state based on voucher pricing alone. In the end, a high voucher amount might well help the state satisfy its affirmative obligation to take steps to diversify the mix of providers, but a low voucher amount is not by itself dispositive in the other direction.

We do not claim that Ohio was obliged by the Constitution to take all three steps that might have ameliorated the constitutional problem caused by its voucher scheme. Nor is it simple to determine whether two of three-and, if so, which two - would suffice. We can say with confidence, however, that a required opt-out from religious education, unlike the other two steps, represents a distinction of kind and not degree. Suburban participation may

tied to public school expenditure (with a cap only to ensure that the reimbursement does not exceed the private school's actual costs), the argument that the state is rigging the market by keying vouchers to sectarian school tuition charges is much harder to sustain. A group of Republican state legislators in Ohio is attempting to increase the voucher amount in the Ohio Scholarship Program, although they are keying the amount to state-wide averages for per pupil expenditures in the public schools, rather than to amounts spent per pupil in Cleveland. See Scott, supra note 179 (reporting that a "group of Republican state senators is backing a bill that would [increase the Cleveland school voucher amount] from $\$ 2500$ to $\$ 4814$, the base amount the state currently spends on each public school student in the state."). 


\section{The Journal of Law and Politics}

have expanded the mix of schools to an uncertain extent; an increase in the voucher amount may have had a similar effect. But opt-outs would dramatically reduce the steering of Scholarship students to intense religious experience, and therefore reduce proportionally the state's - rather than parents'-responsibility for whatever religious training (as opposed to knowledge, sensitivity, or insight) they receive.

With these omissions in mind, might we nevertheless conclude that the State of Ohio has satisfied its affirmative obligation to ensure meaningful choice between sectarian and secular alternatives with the other options it has made available to Cleveland students - tutoring grants, magnet schools, and community schools? ${ }^{182}$ These are indeed secular alternatives to the use of a voucher to attend a religious school, and the crucial question posed by their availability is that of quality. Are they at least reasonably equal in quality to the religious alternatives the Program makes available? There are certainly grounds for doubt. The tutoring grants are limited to $90 \%$ of $\$ 400$ worth of tutoring per academic year; at a rate of $\$ 10$ per hour, which seems extremely low for trained and capable tutors, this would buy approximately one hour of tutoring per week during the school year. It's hard to imagine that the option of remaining in the traditional public schools, and getting one tutoring hour per week, is reasonably equal to full-time attendance at a private school with a long and successful track record for educating young children.

As of the time of the lawsuit in Cleveland, some parents did have the option of enrolling their children at magnet or community schools. For magnet schools to contribute to the "meaningful choice" required by the Establishment Clause to validate the Scholarship Program, the magnet schools must offer educational opportunities roughly equal to the private schools in which Scholarships are used. The magnet schools, however, are being operated by the same school system that the State was obliged to take over because of overwhelmingly poor performance. Before reaching a judgment on the adequacy of the magnet school alternative, courts would need much more information about the quality of teaching, curriculum, and administration, involvement of parents, graduation rates, school-wide test scores, and the like. The record in Zelman simply does not speak to issues of comparative quality between magnet schools and the private schools participating in the Scholarship Program. ${ }^{183}$

182 The Sixth Circuit considered these options irrelevant to the constitutionality of the Scholarship Program. 234 F.3d at 958.

183 This omission from the record may be the result of the lower courts and the parties being unaware that the state faced this burden of persuasion. Alternatively, there may be no evidence of any such equality to be had. See Brief of Amici Curiae Ohio School Boards Association, Ohio Association of School 


\section{Vouchers and Religious Service Providers}

Community ("charter") schools drew a great deal of attention in the oral argument in Zelman in the Supreme Court. ${ }^{184}$ Community schools arguably are closer to the private schools in the voucher program for purposes of analyzing parental empowerment and choice. Community schools are publicly financed, but offer their own educational program and are independent of the City's public school bureaucracy for purposes of personnel, curriculum, and policy. ${ }^{185}$ Moreover, when a parent enrolls a child in a community school, public financing in an amount greater than the tuition award in the Scholarship Program follows the child into the school. ${ }^{186}$ Indeed, one of Ohio's responses to the challenges to the sufficiency of the mix of participating schools has been the assertion that some secular schools switched, for precisely this reason of per pupil financing, from being Scholarship schools to becoming community schools. ${ }^{187}$

The arguments about market dynamism and its effect on the mix are most powerful with respect to community schools; they are far cheaper to bring on line than private schools tend to be, and Ohio is making efforts to subsidize their start-up costs with loan guarantees and low-cost leases of vacant public

Business Officials, Buckeye Association of School Administrators, Ohio Coalition for Equity and Adequacy of School Funding, Coalition of Rural and Appalachian Schools, Ohio Association of Secondary School Administrators, 2000 U.S. Briefs $1751 * 28 \mathrm{n} .19$ ("Any district may create a 'magnet' school simply by adopting a building-wide theme or curriculum designed to appeal to certain students. To say that the State of Ohio has created 'magnet schools' as a distinct nonsectarian 'alternative' is simply a false statement. 'Magnet schools' are created in each instance as a local curricular decision. If petitioners want to inflate the number of nonsectarian 'choices' available to Cleveland parents, they might as well include every building in the Cleveland district. Ohio law requires public schools to have 'open enrollment' within each district. O.R.C. 3313.97.").

184 Transcript of oral argument at 34-44, Zelman v. Simmons-Harris, 2002 U.S. LEXIS 4885 (questioning Robert Chanin, counsel for the Respondents). Chanin's response to questions about the role of community schools in the case, that such schools were part of the State's attempt "to discharge its basic legal obligation to provide a public education for all of its students," $i d$. at 36 , while participating private schools should not count as part of a single basket of publicly-provided school choices - probably doomed his chance to win the case. Although the transcript does not identify questioners, our recollection is that most of the questions on this subject came from Justice O'Connor, and this recollection is buttressed by a pertinent point in the transcript. See id. at 40 ("Question [to Mr. Chanin]: So far, you're doing a very good job of not answering Justice O'Connor's question.”). Both sides need Justice O'Connor's vote, and she seemed to believe that community schools, along with private schools participating in the Scholarship Program, should indeed count as part of the choices available to Cleveland parents. The only winning answer for Chanin would be that community schools are too few, too new, and too unproven to suffice. That answer, however, was presumably precluded both by the position he took in his written brief, see Respondents' Brief in Simmons-Harris v. Zelman, 2000 U.S. Briefs 1751, at 26-29, and by the staunch antivoucher political position of his clients, the public school teachers' unions.

185 Puckett Affidavit, supra note 138, at 157a..

186 Id. at $163 \mathrm{a}$.

187 Greene Affidavit, id. at 217a-218a; Brief of Amici Curiae United States, supra note 130, at 23 (citing Joint Appendix at 145a-146a, 217a-218a, Zelman v. Simmons-Harris, 2002 U.S. LEXIS 4885. 


\section{The Journal of Law and Politics}

school buildings. ${ }^{188}$ Nevertheless, substantial per pupil funding obviously did not make the traditional Cleveland public schools a good alternative; their per pupil expenditure is the highest of all the schools available for parental choice, and their quality seems to be the lowest. With respect to outputs, more relevant to parental choice, community schools present a problem of information availability akin to that presented by magnet schools; they constitute an intriguing new aspect of the overall mix of schools, but the number of them remains small, their enrollments are low, and most of them in Cleveland (and elsewhere) are extremely new and so cannot be easily measured on grounds of educational outputs. Indeed, there were only three community schools in Cleveland in 1998-99, and seven additional schools acquired that status in 1999-2000, the relevant year for the Zelman litigation. ${ }^{189}$ Moreover, the fact that they receive on average more money per enrolled pupil may explain why some schools switched from private status to community status, but cannot by itself ensure their adequacy as an alternative.

In any event, the federal courts in the Cleveland voucher case made no effort to measure the quality of magnet or community schools as alternatives to private, religious schools participating in the Scholarship Program. If we are right that the State must bear the burden of demonstrating that it has made a good faith effort to avoid steering students toward religious training, or that in any event the provider mix between the secular and sectarian is constitutionally sufficient, what should the Supreme Court do? As we have been suggesting, the minimally sufficient efforts, and conditions of choice, necessary to avoid State responsibility for religious experience require difficult line drawing. Nevertheless, our overarching framework leads us to conclude that the Supreme Court should affirm the Sixth Circuit. Taken all together, the inattention to requiring religious opt-outs for voucher students by participating religious schools, the absence of mandatory suburban participation, the low voucher amounts, and the lack of information about the quality rather than quantity of other available options suggest that Ohio has been doing what the Establishment Clause forbids - relying heavily upon sectarian schools precisely because of their religious character, and the sort of discipline associated with that character. If that is correct, it is surely

188 For details on Ohio's support for community schools ("charter schools"), see http://www.edreform.com/charter_schools/laws/Ohio.htm.

189 Puckett Affidavit, supra note 137. The timing of these schools' openings in Cleveland suggests that it is primarily a matter of fortuity that they appear to be playing a central role in the Supreme Court's deliberations. If the Cleveland voucher case had never been commenced in state court, and if the litigation had begun immediately in federal court, and proceeded to the Supreme Court in an earlier year, the community schools would not be playing the significant role that they are in the question of "parental choice." 


\section{Vouchers and Religious Service Providers}

reasonable to attribute to the State the religious experience that voucher students receive in these schools, whether or not the State has intentionally sought that experience for Scholarship students.

If, however, the Supreme Court believes that community and magnet schools may be shown to be sufficient in both quality and quantity to absolve the state of constitutional responsibility for religious training received by Scholarship students, the Court might vacate the judgment and remand the case to the lower courts for findings on these questions. The Scholarship Program has laudable and important goals, and it is, after all, harsh to rule against Ohio on the basis of a placement of a proof burden not clearly identified prior to the litigation. Although a remand on this basis would prolong the already extended struggle in Cleveland, such a disposition would send a constitutionally appropriate signal to lower courts and, more importantly, to the designers of public-private partnerships in the provision of public services, about how to think about the constitutionality of voucher programs. At a moment in our history in which the future of partnerships between government and faith-based organizations is at a fateful crossroads, strong but sensitive judicial guidance on this question would be most salutary.

\section{CONCLUSION}

The Cleveland case aside, our analysis in this paper leads us to a few stark conclusions. Voucher financing may indeed be a way to involve faithintensive institutions in the provision of state-supported service. Most assuredly, voucher financing offers the possibility of such inclusion, without modification of the faith program, far beyond what programs supported by non-voucher financing may allow. This insight may be of particular importance to the architects of charitable choice arrangements over the coming decade.

However buoyed the proponents of vouchers - for education, substance abuse treatment, or otherwise - may be as a result of this possibility, they must recognize the constitutional responsibility the State undertakes when it pursues the voucher route. The State may not steer recipients to religious experience, and some voucher contexts will produce much more aggressive steering than others. Recognizing the differences among programs, and trying to design programs in ways that meet the responsibilities commensurate with these differences, are the first steps toward constitutional success in this regard. When those who design government services select from the thick catalogue of options to which we referred in the opening sentence of this

piece, they must understand that inducing the needy and vulnerable to come 
The Journal of Law and Politics

to religious faith is not an appropriate instrument of state policy. Programs designed to do just that push the State into territory forbidden by the Constitution, which, properly understood, protects the enterprise of religious devotion by leaving it in the hands of the people and beyond the grasp of state power. 